Int. J. Dev. Biol. 48: 411-424 (2004)

\title{
Matrix metalloproteinases in cancer: from new functions to improved inhibition strategies
}

\author{
ALICIA R. FOLGUERAS, ALBERTO M. PENDÁS, LUIS M. SÁNCHEZ and CARLOS LÓPEZ-OTÍN* \\ Department of Biochemistry and Molecular Biology, Faculty of Medicine, University Institute of Oncology, Universidad de Oviedo, Spain
}

\begin{abstract}
Over the last years, the relevance of the matrix metalloproteinase (MMP) family in cancer research has grown considerably. These enzymes were initially associated with the invasive properties of tumour cells, owing to their ability to degrade all major protein components of the extracellular matrix (ECM) and basement membranes. However, further studies have demonstrated the implication of MMPs in early steps of tumour evolution, including stimulation of cell proliferation and modulation of angiogenesis. The establishment of causal relationships between MMP overproduction in tumour or stromal cells and cancer progression has prompted the development of clinical trials with a series of inhibitors designed to block the proteolytic activity of these enzymes. Unfortunately, the results derived from using broad-spectrum MMP inhibitors (MMPIs) for treating patients with advanced cancer have been disappointing in most cases. There are several putative explanations for the lack of success of these MMPIs including the recent finding that some MMPs may play a paradoxical protective role in tumour progression. These observations together with the identification of novel functions for MMPs in early stages of cancer have made necessary a reformulation of MMP inhibition strategies. A better understanding of the functional complexity of this proteolytic system and global approaches to identify the relevant MMPs which must be targeted in each individual cancer patient, will be necessary to clarify whether MMP inhibition may be part of future therapies against cancer.
\end{abstract}

KEY WORDS: angiogenesis, metastasis, proteases, degradome.

\section{Introduction}

The ability of cancer cells to invade other tissues and spread to distant organs is an often-fatal characteristic of malignant tumours. Proteolytic enzymes play a fundamental role in cancer progression providing an access for tumour cells to the vascular and lymphatic systems, which support tumour growth and constitute an escape route for further dissemination (Chambers et al., 2002; Mareel and Leroy 2003). The complexity of proteolytic systems operating in human tissues is impressive, as assessed by the finding that more than 500 genes encoding proteases or protease-like proteins are present in the human genome (Puente et al., 2003). However, among all the proteolytic enzymes potentially associated with tumour invasion, the members of the MMP family have reached an outstanding importance due to their ability to cleave virtually any component of the ECM and basement membranes, thereby allowing cancer cells to penetrate and infiltrate the subjacent stromal matrix (Brinckerhoff and Matrisian 2002). Although the mechanistic process of ECM degradation mediated by MMPs had been the focus of many investigations for years, recent studies have shown that the role of MMPs in cancer progression is much more complex than that derived from their direct degradative action on ECM components (Egeblad and Werb 2002; Freije et al., 2003; Hojilla et al., 2003). Growth-factor receptors, cell adhesion molecules, chemokines, cytokines, apoptotic ligands, and angiogenic factors are just some examples of the diversity of substrates targeted by MMPs. The recent characterization of new MMP substrates as well as the generation of genetically modified animal models of gain or loss of MMP function, have demonstrated the relevance of MMP activities in the early stages of cancer development. These observations emphasize the importance of re-evaluating the anti-cancer trials that have been developed to inhibit MMPs (Coussens et al., 2002; Overall and Lopez-Otin 2002; Pavlaki and Zucker 2003). The purpose of this review is to present the current knowledge on the functional complexity of the MMP family and to discuss the implications of this new information for designing improved MMPinhibition strategies for cancer therapy.

Abbreviations used in this paper: ECM, extracellular matrix; MMP, matrix metalloproteinase; MMPI, MMP inhibitor.

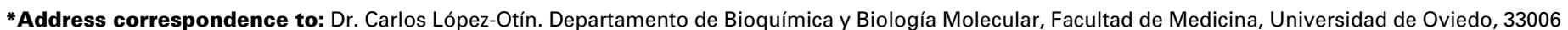
Oviedo, Spain. Fax: +34-985-103-564. e-mail: CLO@correo.uniovi.es
} 


\section{Structural diversity of MMPs}

The availability of the complete human genome sequence has allowed to define the complete set of MMPs produced by human cells. Thus, recent genomic studies have revealed that there are 24 distinct genes encoding members of the MMP family (Puente etal., 2003). Analysis of the structural design of these enzymes has led to a new classification system based on MMP structures rather than on their substrate specificities (Fig. 1). Most of them are organized around a conserved catalytic domain which incorporates a propeptide necessary to maintain enzyme latency, a signal peptide which directs their secretion from the cell, and a Cterminal hemopexin domain which contributes to substrate specificity and to interactions with endogenous inhibitors (Overall 2002). This archetypal MMP design is present in the subgroup of secreted proteases composed of the three human collagenases (MMP-1, MMP-8, and MMP-13), the two stromelysins (MMP-3 and MMP-10), and four additional MMPs with unique structural characteristics (MMP-12, MMP-19, MMP-20, and MMP-27). Besides the archetypal conformation, the two matrilysins (MMP-7 and MMP-26) lack the hemopexin domain (Uria and Lopez-Otin 2000) and the two gelatinases (MMP-2 and MMP-9) incorporate three fibronectin type II modules that provide a compact collagenbinding domain (Morgunova et al., 1999). In addition to these secreted MMPs, there are six membrane-type (MT)-MMPs localized at the cell surface through a C-terminal transmembrane domain (MT1-, MT2-, MT3- and MT5-MMP) or by a glycosylphosphatidylinositol anchor (MT4- and MT6-MMP) (Zucker et al., 2003). The MT-MMPs also have an additional insertion of basic residues between the propeptide and the catalytic domain, which is cleaved by furin-like serine proteases leading to the intracellular activation of the proenzymes (Thomas 2002; Zucker et al., 2003). This furin-like cleavage site is also present in three secreted MMPs (MMP-11, MMP-21 and MMP-28) that do not fit to any of the previous subgroups and in two unusual transmembrane MMPs, (MMP-23A and MMP-23B), which are anchored through an N-terminal segment and show identical amino acid sequence, despite being encoded by two distinct human genes (Pei et al., 2000; Velasco et al., 1999).

To date, and despite significant advances in x-ray crystallography and nuclear magnetic resonance techniques, human MMP2 is the only MMP family member whose full-length structure has been solved (Morgunova et al., 1999). In addition, the 3D structures of different domains of a number of MMPs have been determined (Bode 2003; Visse and Nagase 2003) (http:// www.rcsb.org/pdb/). Nevertheless, it should be essential to increase the number of structures available for MMPs, to better understand the variety of substrates that these enzymes can target as well as to allow the design of more selective MMP inhibitors (MMPIs).

\section{The biology of MMPs}

The evolution of the MMP family to generate this structural diversity likely reflects the number and complexity of biological processes in which these enzymes are involved. The identification of new MMP substrates and the development of genetically modified animal models with gain or loss of MMP function, have demonstrated the relevance of these proteases in multiple physiological processes (Vu and Werb 2000) (Tables 1 and 2).



Fig. 1. Diversity of human MMPs. Structural classification of human MMPs based on their domain organization. 


\section{Physiological functions of MMPs}

Embryonic growth and tissue morphogenesis are fundamental events that require disruption of ECM barriers to allow cell migration and matrix microenvironment remodelling. The ability of MMPs to degrade structural components of ECM and basement mem- branes has supported their direct implication in these processes. In fact, research on the MMP field started with the finding that a collagenolytic activity was responsible for a major developmental event: the tail resorption during metamorphosis in tadpoles (Brinckerhoff and Matrisian 2002; Gross and Lapiere 1962). Nevertheless, the discovery that MMPs are also able to release or process bioactive molecules in addition to their classical degradative properties on structural proteins has provided a new opportunity to appreciate the importance of these enzymes in many biological functions (Vu and Werb 2000).

Most MMP genes are highly expressed in a number of reproductive processes, including menstrual cycle, ovulation, and uterine, breast and prostate involution (Curry and Osteen 2003; Hulboy et al., 1997). Thus, matrilysin, stromelysins and gelatinase $A$ are consistently produced during the most active phases of the murine estrous cycle. These MMPs, as well as collagenase2 and collagenase- 3 , are also up-regulated during postpartum uterus involution (Balbin etal., 1998; Rudolph-Owen etal., 1997). In addition, the expression patterns of several MMP genes have been analyzed during gonadotropininduced ovulation, in order to identify those members responsible for follicular wall degradation (Curry and Osteen 2003; Hagglund etal., 1999). However, none of the mutant mice deficient in specific MMPs which have been generated to date show a significant reproductive dysfunction. This finding suggests that functional redundancy among MMPs, or between these enzymes and components of the plasminogen system may compensate for the loss of a specific MMP (Ny et al., 2002; Solberg et al., 2003).

The relevance of MMPs in embryonic development has prompted the identification and characterization of new members of this family in model organisms such as Drosophila, where developmental processes have been extensively studied (Llano et al., 2002; Llano et al., 2000). The discovery that Drosophila has only two MMPs has allowed for the first time the complete ablation of all MMPs in any organism, through the creation of a double mutant (Page-McCaw et al., 2003). This study has demonstrated that, in flies, MMPs are required for tissue remodelling but not for embryonic development. However, the importance of mammalian 
MMPs in this process can be appreciated from the early implantation stages, where the production of MMP-9 by invading trophoblasts seems to be critical (Alexander et al., 1996). Furthermore, studies with Mmp9-deficient mice have demonstrated the in vivo role of this protease in a number of developmental processes. Thus, these mice exhibit a defect in endochondral bone formation, which is accompanied by delayed apoptosis of hypertrophic chondrocytes at the skeletal growth plates and deficient vascularization (Vu et al., 1998). Targeted inactivation of the MT1-MMP gene in mice also causes several skeletal and connective tissue defects, as well as defective angiogenesis, leading to premature death (Holmbeck et al., 1999; Zhou et al., 2000).

The role of MMPs in tissue remodelling has also been demonstrated in several reports. MMP-2 and MMP-3 regulate mammary gland branching morphogenesis during puberty (Wiseman et al., 2003). MMP-2 and MMP-9 also contribute to adipogenesis by promoting adipocyte differentiation (Bouloumie et al., 2001). However, other MMPs seem to have an inhibitory effect in this process. Thus, Mmp3-deficient mice show accelerated adipogenesis during mammary gland involution (Alexander etal., 2001). MMPs are also involved in wound healing, a tissue-remodelling process which involves the migration of keratinocytes at the edge of the wound to re-epithelialize the damaged surface. Several studies in cell culture have shown that the proteolytic activity of MMP-1 is required for keratinocyte migration (Pilcher et al., 1997). The in vivo role of MMPs in this process has been supported by the analysis of Mmp3deficient mice, which exhibit impaired wound contraction (Bullard et al., 1999), and by studies in collagenase-resistant mice which also show a severe delay in wound healing (Beare et al., 2003). However, the complete inhibition of the healing process requires the blockade of both plasminogen and MMP proteolytic activities, indicating again a functional overlap between both classes of matrix-degrading proteases (Lund et al., 1999).

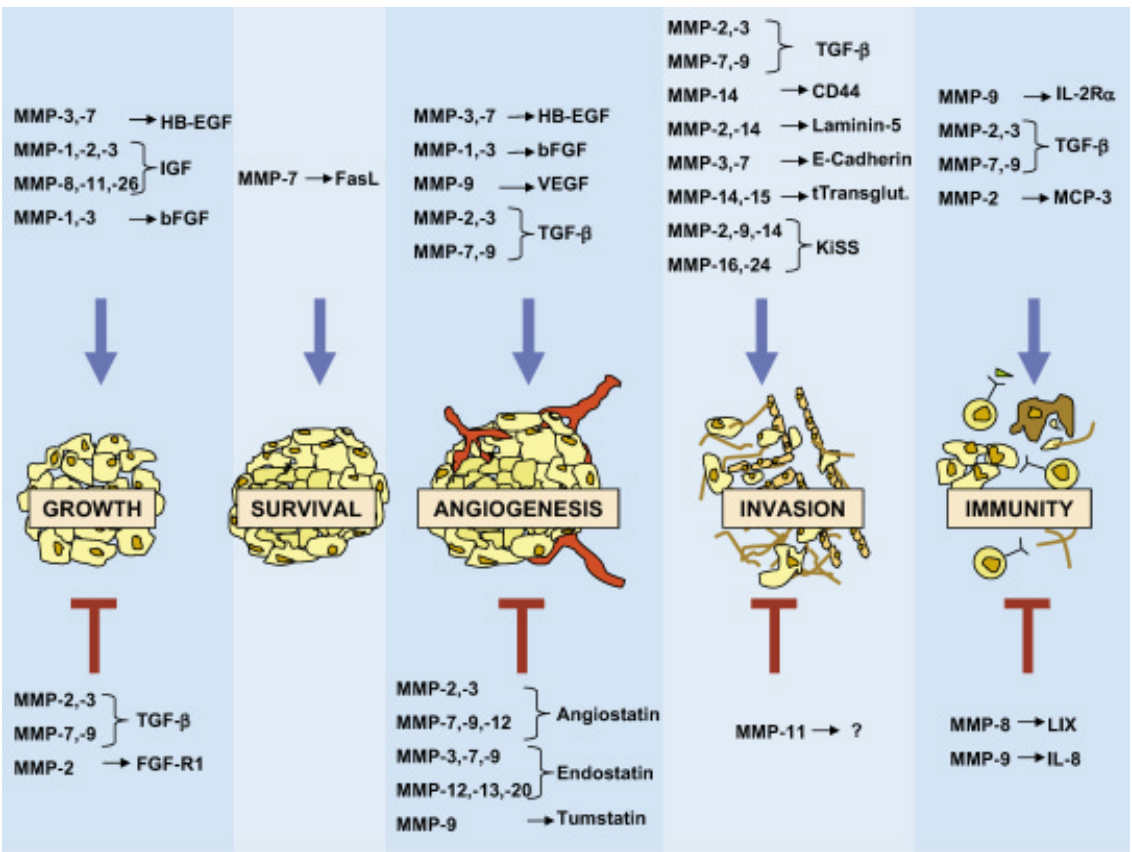

Fig. 2. Dual functions of MMPs in tumour progression. The opposite effects of bioactive molecule processing by MMPs on cancer development are shown.
The role of MMPs in angiogenesis is also wide and complex. Many MMPs are produced by endothelial cells and have been described to be important for the formation of new blood vessels in both physiological and pathological conditions. For example, MMP2 associates with integrin $\alpha v \beta 3$, and this interaction is essential for localizing the enzyme to the surface of newly forming vessels (Brooks et al., 1994). Further studies examining the links between MMP-2 and angiogenesis have shown that, after different challenges, Mmp2-null mice show reduced vascularization compared to wild-type controls (Itoh et al., 1998; Lambert et al., 2003). The finding that choroidal neovascularization is severely impaired in Mmp2/Mmp9-double deficient mice has demonstrated the synergic effect of both proteases in this process (Lambert et al., 2003). In addition, enzymatic studies have revealed that the endogenous angiogenic inhibitor endostatin can block the activation or the catalytic activities of MMP-2, MMP-9, MMP-13 and MT1-MMP (Kim et al., 2000; Lee et al., 2002; Nyberg etal., 2003). MMPs may also regulate angiogenesis by acting as pericellular fibrinolysins during the neovascularization process (Hiraoka et al., 1998). Finally, many members of the MMP family show a dual ability to mobilize or activate pro-angiogenic factors or angiogenic inhibitors. The relevance of these MMP functions in cancer will be further discussed in this review.

\section{MMP roles in cancer}

The identification of novel biological functions for MMPs has prompted the evaluation of their relevance in cancer beyond the classical MMP roles of ECM disruption in late invasive stages of the disease. Thus, proteolytic processing of bioactive molecules by MMPs contributes to the formation of a complex microenvironment that promotes malignant transformation in early stages of cancer. These additional functions mediated by MMPs include activation of growth factors, suppression of tumour cell apoptosis, destruction of chemokine gradients developed by host immune response, or release of angiogenic factors (Egeblad and Werb 2002; Hojilla et al., 2003) (Fig. 2) (Table 2).

There is an increasing evidence supporting the participation of MMPs in the regulation of tumour growth by favouring the release of cell proliferation factors such as insulin-like growth factors which are bound to specific binding proteins (IGFBPs) (Manes et al., 1997). MMPs may also target and activate growth factors whose precursors are anchored to the cell surface or sequestered in the peritumour ECM (Yu and Stamenkovic 2000). Furthermore, a recent study has illustrated the direct effect of MMP matrix remodelling activity on cell growth (Hotary et al., 2003). This interesting work has shown that the expansion of tumour cells inside a three-dimensional collagen-matrix is significantly enhanced in response to MT1-MMP overexpression. By contrast, overproduction of a number of soluble MMPs did not have any effect on tumour cell growth (Hotary et al., 2003). The ability of MT1MMP to confer this proliferative advantage to tumour cells is not apparent when cells are placed in a two-dimensional system, confirming 
the importance of physical presentation of the surrounding ECM on cell behaviour (Cukierman et al., 2001). Nevertheless, it is remarkable that tumour cells may develop protease-independent migratory mechanisms in response to the blockade of pericellular proteolysis (Wolf et al., 2003).

The ability of MMPs to target substrates that influence the apoptotic process is also relevant for cancer. Thus, MMP-3 has pro-apoptotic actions on the neighbouring epithelial cells (Witty et al., 1995), whereas MMP-7, which is able to release the membrane-bound Fas ligand, also induces epithelial cell apoptosis (Powell et al., 1999). This cleavage can also favour tumour progression as a result of the protection that FasL confers to cancer cells from chemotherapeutic drug cytotoxicity (Mitsiades et al., 2001). Also in this regard, it is of interest that mice deficient in MMP2, MMP-3 or MMP-9 have lower levels of apoptosis induced by TNF- $\alpha$, which has suggested that MMPIs may be useful in cancer therapies using inflammatory cytokines (Wielockx et al., 2001). Other MMPs, such as MMP-11, suppress tumour cell apoptosis inhibiting cancer cell death (Boulay et al., 2001). This finding suggests that the targeting of MMP-11 activity could lead to survival benefits for cancer patients. However, a paradoxical effect for this MMP in cancer has been recently described. Thus, Mmp11\% MMTV-ras transgenic mice develop more metastasis than their Mmp11+/+MMTV-ras counterparts, despite the lower number and size of primary tumours (Andarawewa et al., 2003). These data imply that in addition to its antiapoptotic action, MMP11 should have another molecularfunction that leads to decreased metastatic rate. This observation emphasises the importance of selectively targeting certain MMP functions instead of completely blocking their activity.

MMP activities have also been traditionally associated with a variety of escaping mechanisms that cancer cells develop to avoid host immune response (Coussens et al., 2000; Coussens and Werb 2002). Some MMPs, such as MMP-9, can suppress the proliferation of $T$ lymphocytes through the disruption of the IL-2R $\alpha$ signalling (Sheu et al., 2001). Likewise, MMP-11 decrease the sensitivity of tumour cells to natural killer cells by generating a bioactive fragment from $\alpha 1$-proteinase inhibitor (Kataoka et al., 1999). In addition, MMPs may modulate antitumour immune reactions through their ability to efficiently cleave several chemokines or regulate their mobilization (Li etal., 2002; McQuibban et al., 2000; Van den Steen et al., 2002). However, MMPs may also be beneficial to the host by stimulating protective and adaptive immune responses. Thus, a recent report has revealed that mutant male mice deficient in MMP-8 exhibit an increased tumour susceptibility compared to wild-type mice (Balbin et al., 2003). Histopathological analysis of these Mmp8-deficient mice has revealed the presence of abnormalities in the inflammatory response induced by carcinogens. In fact, the lack of this MMP hampers the early stages of inflammation, but once established it is abnormally sustained leading to a more favourable environment for tumour development. The prolonged accumulation of inflammatory cells likely results in chronic inflammation which facilitates genomic instability and promotion of tumour growth (Coussens and Werb 2002). Therefore, and contrary to previous studies performed with mice lacking specific MMPs, loss of MMP-8 enhances rather than reduces tumour susceptibility. A putative mechanism to explain these paradoxical effects of a MMP family member comes from its potential proteolytic processing activity on inflammatory mediators, which could contribute to the host antitumour defense system. We are currently evaluating the possibility that MMP-8 could play a role in the proteolytic inactivation of

TABLE 2

\section{PHENOTYPES OF MICE WITH GENETIC MODIFICATIONS IN THE MMP SYSTEM}

\begin{tabular}{|c|c|c|}
\hline $\begin{array}{l}\text { Genetically } \\
\text { modified mice }\end{array}$ & Phenotype & Tumour development \\
\hline \multicolumn{3}{|l|}{ Transgenic mice } \\
\hline Haptoglobin-Mmpl & Hyperkeratosis, acanthosis & Increased skin carcinogenesis \\
\hline WAP-Mmp3 & Precocious alveolar branching morphogenesis & Increased mammary carcinogenesis \\
\hline MMTV-Mmp3 & Mammary epithelial cell apoptosis & Increased mammary carcinogenesis \\
\hline MMTV-Mmp7 & Disorganized testis, infertility & Increased mammary carcinogenesis \\
\hline MMTV-Mmp14 & Mammary hyperplasia & Increased mammary carcinogenesis \\
\hline \multicolumn{3}{|l|}{ Knock-out mice } \\
\hline$M m p 2^{-/-}$ & $\begin{array}{l}\text { Reduced angiogenesis } \\
\text { Delayed mammary gland differentiation }\end{array}$ & $\begin{array}{l}\text { Reduced pancreatic carcinogenesis } \\
\text { Decreased tumour growth }\end{array}$ \\
\hline $\mathrm{Mmp3}^{-/-}$ & $\begin{array}{l}\text { Accelerated mammarygland adipogenesis } \\
\text { Delayed incisional wound healing } \\
\text { Resistance to contact dermatitis } \\
\text { Impaired ex vivo herniated disc resorption }\end{array}$ & \\
\hline$M m p 7^{-1-}$ & $\begin{array}{l}\text { Defective innate intestinal immunity } \\
\text { Impaired tracheal wound repair } \\
\text { Impaired migration of neutrophils } \\
\text { Defective prostate involution } \\
\text { Impaired ex vivo herniated disc resorption }\end{array}$ & Reduced intestinal adenoma formation \\
\hline$M m p 8^{-/-}$ & Defective inflammatory response & Increased skin carcinogenesis in males \\
\hline $\operatorname{Mmp} 9^{-/}$ & $\begin{array}{l}\text { Delayed growth plate vascularization } \\
\text { Defective endochondral ossification } \\
\text { Defective in osteoclast recruitment } \\
\text { Resistance to bullous pemphigoid } \\
\text { Resistance to aortic aneurysms } \\
\text { Prolonged contact dermatitis } \\
\text { Abnormal embryonic implantation } \\
\text { Protection from cardiac rupture after infarction } \\
\text { Diminished neutrophilinfiltrate in glomerular nephritis }\end{array}$ & $\begin{array}{l}\text { Reduced skin carcinogenesis } \\
\text { Reduced pancreatic carcinogenesis } \\
\text { Reduced experimental metastasis } \\
\text { Reduced pancreatic carcinogenesis }\end{array}$ \\
\hline Mmp11 1 & Accelerated neointima formation after vessel injury & $\begin{array}{l}\text { Reduced mammary carcinogenesis } \\
\text { Decreased tumour cell survival and growth } \\
\text { Increased number of metastasis }\end{array}$ \\
\hline $\operatorname{Mmp} 12^{-/}$ & Resistance to cigarette-smoke-induced emphysema & \\
\hline Mmp14\% & $\begin{array}{l}\text { Severe abnormalities in bone and connective tissue } \\
\text { Defective angiogenesis } \\
\text { Premature death }\end{array}$ & \\
\hline $\operatorname{Mmp} 20^{-/-}$ & Amelogenesis imperfecta & \\
\hline
\end{tabular}


proinflammatory cytokines or chemokines, thereby contributing to the appropriate resolution of inflammatory responses induced by carcinogens.

The role of MMPs in angiogenesis is also dual and complex. The relevance of these enzymes as positive regulators of tumour angiogenesis has been largely demonstrated. Thus, several pro-angiogenic factors such as vascular endothelial growth factor (VEGF), basic fibroblast growth factor (bFGF) or transforming growth factor$\beta$ (TGF- $\beta$ ) are induced or activated by these enzymes, triggering the angiogenic switch during carcinogenesis and facilitating vascular remodelling and neovascularization at distant sites (Belotti et al., 2003; Bergers et al., 2000; Mohan et al., 2000; Sounni et al., 2002; $\mathrm{Yu}$ and Stamenkovic 2000). An additional connection between angiogenic factors and MMPs derives from the recent finding that MMP-9 is induced in tumour macrophages and endothelial cells and promotes lung metastasis (Hiratsuka et al., 2002). Furthermore, host-derived MMP-9 contributes to the malignant behaviour of ovarian carcinomas by promoting neovascularization (Huang et al., 2002). However, and contrary to these proangiogenic roles of MMPs, the recent description of mechanisms by which these enzymes negatively regulate angiogenesis has contributed to increase the functional complexity of this proteolytic system in cancer. Thus, a number of MMPs are able to cleave the precursors of angiostatin and endostatin, and generate the active forms of these endogenous inhibitors of angiogenesis (Cornelius et al., 1998; Ferreras et al., 2000). Furthermore, a recent study has correlated the generation of tumstatin by MMP-9-mediated proteolysis of type IV collagen, with the suppression of pathological angiogenesis and tumour growth (Hamano et al., 2003).

Taken together, these findings illustrate the diversity of MMP functions associated with cancer and highlight the importance of MMP protective activities in tumour progression, an aspect that had been largely overlooked in this field. Hence, it is critical to identify the physiological role of each individual MMP and its specific participation in the multiple stages of tumour evolution to better develop effective therapeutic interventions.

\section{Regulation of MMPs}

In order to block the undesired activities of MMPs in cancer, it is first necessary to understand the precise mechanisms that regulate MMP expression and activity in both physiological and pathological conditions. Despite the complexity of MMP regulation, three major levels of endogenous control can be recognized: gene transcription, proenzyme activation and inhibition of their enzymatic activity. Collectively, these mechanisms should confine MMP degradative activity to those sites and situations where it is biologically necessary. However, tumour cells have developed multiple strategies to escape these checkpoints controlling the MMP proteolytic activity, acquiring new properties that lead to tumour growth and invasion.

\section{Transcriptional regulation}

The absence of a universal mechanism responsible for the observed MMP overexpression in tumours may be a consequence of the multiple cells contributing to the synthesis of these enzymes during cancer evolution. Thus, in addition to their production by epithelial tumour cells, MMP gene expression may be induced in stromal fibroblasts, or in vascular and inflammatory cells that infiltrate tumours (De Wever and Mareel 2003; Nielsen et al., 2001). Accordingly, MMP induction mechanisms appear to be different depending on the characteristics of the diverse cells with ability to produce these enzymes. A wide variety of agents, including cytokines, growth factors and oncogene products cause spatial and temporal variations of MMP expression (Westermarck and Kahari 1999). Nevertheless, TNF- $\alpha$ and IL-1 are regularly implicated in MMP gene induction in different tumours, whereas TGF- $\beta$ or retinoids usually repress MMP transcription. However, there are several exceptions to this situation, since some family members such as Mmp11 or Mmp13 can be induced rather than repressed by these factors in diverse cell types (Guerin et al., 1997; Overall et al., 1989; Uria et al., 1998). It is also possible to find similarities among the signal-transduction pathways mediating induction of different MMPs. Thus, the ERK and the p38 mitogen activated protein kinase pathways are relevant in a number of cases (Pan and Hung 2002; Reunanen et al., 2002; Ruhul Amin et al., 2003; Tanimura et al., 2003).

Structural and functional analysis of the promoter regions from a number of MMP genes has provided a better understanding of the mechanisms that regulate their expression. These studies have revealed the existence of an AP-1 binding site in the promoter of most MMP genes (Pendas et al., 1997). This enhancer element binds homodimers or heterodimers of the Fos and Jun family of oncoproteins, thereby providing an interesting connection between transcription factors related to malignant transformation and MMP expression. Likewise, the PEA3 site which binds the ETS family of oncoproteins, is also present in many MMP gene promoters (Crawford et al., 2001). It has been demonstrated that the ETS and AP-1 binding sites cooperate to enhance transcription, although the presence of other upstream elements such as NF- $\mathrm{kB}$ or Cbfa1 binding sites is also necessary to precisely regulate MMP gene expression and tissue specificity (Bond et al., 1998; Jimenez et al., 2001). Finally, it is important to emphasize the presence in several MMP gene promoters, of single nucleotide polymorphisms (SNPs) with ability to influence cancer susceptibility. One of these SNPs identified in the Mmp1 promoter creates an ETS binding site that enhances transcription of $M m p 1$, and is associated with several cancers (Tower et al., 2003; Wyatt et al., 2002; Zhu et al., 2001). Additional SNPs influencing cancer susceptibility have also been reported in the promoter of other MMPs such as Mmp2, Mmp3and Mmp7(Ghilardi et al., 2002; Ghilardi et al., 2003; Miao et al., 2003; Yu et al., 2002).

\section{Proenzyme activation}

MMPs, like most proteolytic enzymes, are synthesized as inactive zymogens. Therefore, the activation of proMMPs represents another step in the regulation of MMP activity. Several agents such as thiol-modifying reagents, mercurial compounds, reactive oxygen radicals, a variety of denaturant agents, as well as conditions of low $\mathrm{pH}$ and high temperature, can lead to MMP activation in vitro (Nagase 1997). This activation is mainly achieved through the disturbance of the interaction between a cysteinesulphydryl group in the propeptide domain and the zinc ion bound at the catalytic site. This mechanism, known as the cysteine-switch model, has been supported by structural analysis and represents a general model for maintaining proMMP latency (Morgunova et al., 1999; Van Wart and Birkedal-Hansen 1990). In vivo, MMP activation requires the participation of other proteases to remove 
the propeptide domain. In most cases, these activating proteases form part of a proteolytic cascade that takes place in the immediate pericellular space (Lijnen 2001). The finding that MT-MMPs are able to activate some proMMPs has provided strong support to this concept (Morrison et al., 2001; Nie and Pei 2003; Sato et al., 1994; Strongin et al., 1995; Zucker et al., 2003). In contrast to the pericellular mechanism of proMMP activation, a set of MMPs, including MT-MMPs, MMP-11, MMP-23 and MMP-28, possesses a furin-like recognition sequence in the propeptide which allows their intracellular activation by furin-like proprotein convertases (Lohi et al., 2001; Pei and Weiss 1995; Yana and Weiss 2000; Zucker et al., 2003). Finally, it is remarkable that alternative MMP activation mechanisms have been recently described. These mechanisms may be based on the formation of an S-nitrosylated derivative with the thiol group of the cysteine switch ( $\mathrm{Gu}$ et al., 2002), or can be mediated in vivo by the MMP binding to a ligand or to a substrate (Bannikov et al., 2002).

\section{Endogenous inhibitors}

The activity of MMPs may be also controlled by a series of endogenous inhibitors. Some of them are general protease inhibitors such as $\alpha 2$-macroglobulin, which mainly blocks MMP activity in plasma and tissue fluids, whereas other inhibitors such as TIMPs (tissue inhibitors of metalloproteinases) are more specific. Four TIMPs have been identified in vertebrates (Brew et al., 2000). TIMP-1, TIMP-2 and TIMP-4 are secreted proteins whereas TIMP3 is anchored in the ECM. All of them share a conserved structure divided into an $\mathrm{N}$ - and a $\mathrm{C}$-terminal domain and containing three conserved disulfide bonds (Williamson et al., 1990). Although it had been described that TIMPs reversibly inhibited MMPs in a stoichiometric manner, the mechanism of interaction remained unknown until the 3D structure of the TIMP-1/MMP-3 complex was solved (Gomis-Ruth et al., 1997). This structure has demonstrated that the TIMP-1 N-terminal domain is the main responsible for MMP inhibition through its binding to the catalytic site in a substrate-like manner. The four TIMPs can inhibit the active form of all MMPs tested to date, although TIMP-1 is a poor inhibitor of MMP19 and of some MT-MMPs (Lee et al., 2003). It is also remarkable the ability of TIMP-3 to block the activity of certain ADAMs (a disintegrin and metalloproteinase) and ADAM-TSs (ADAMs with thrombospondin domains) (Amour et al., 2000; Kashiwagi et al., 2001). The inhibitory activities of TIMPs suggest that the net balance between MMPs and TIMPs is a major determinant of the proteolytic potential of tumours. This concept has been supported by several studies showing that overproduction of TIMPs reduces experimental metastasis (DeClerck and Imren 1994), whereas low levels of these inhibitors correlate with tumorigenesis (Khokha et al., 1989). Moreover, TIMP-2 inhibits endothelial cell proliferation in vitro and angiogenesis in vivo through a MMP-independent mechanism (Seo et al., 2003). Likewise, TIMP-3 can also block the binding of VEGF to VEGF receptor-2, thereby inhibiting downstream signalling and angiogenesis (Qi et al., 2003). However, several studies have shown that TIMP levels are also increased during tumour progression and may exhibit growth promoting activities on a number of cell types, indicating that their role in cancer progression is much more complex than that derived from MMP inhibitory function (Baker et al., 2002; Jiang et al., 2002).

In addition to the inhibitory action of TIMPs, MMP function may be also blocked by a number of proteins recently described. Some of these novel MMP endogenous inhibitors contain sequences with certain similarity to the N-terminal domain of TIMPs. This is the case of the procollagen $\mathrm{C}$-terminal proteinase enhancer (Mott et al., 2000), the NC1 domain of type IV collagen (Petitclerc et al., 2000), or the tissue factor pathway inhibitor-2 (Herman et al., 2001). Finally, RECK (reversion-inducing cysteine-rich protein with kazal motifs) is a membrane-bound protein with ability to act as a MMP inhibitor (Liu et al., 2003; Oh et al., 2001). Taken together, all these observations reflect the diversity of the MMP endogenous inhibitors and the complexity that can be derived from their activities in physiological and pathological conditions, including cancer.

\section{Strategies for MMP inhibition in cancer therapy}

The relationship between MMPs overproduction and tumour progression has prompted the development of a variety of strategies aimed to block the proteolytic activities of these enzymes. However, most clinical trials using MMP inhibitors have yielded disappointing results (Coussens et al., 2002; Overall and LopezOtin 2002; Pavlaki and Zucker 2003). The recent recognition of the complex roles that these enzymes play during physiological and pathological conditions may explain the lack of success of the first generation of MMPIs. Accordingly, the increased knowledge on this proteolytic system may lead to the development of new strategies of MMP inhibition, based on targeting any of the three major levels of endogenous regulation of these enzymes: transcription, activation and inhibition (Freije et al., 2003; Overall and Lopez-Otin 2002).

\section{Targeting MMP gene transcription}

There are three main approaches for targeting MMP gene transcription: preventing the action of extracellular factors, blocking signal-transduction pathways, and targeting those nuclear factors that enhance the expression of the corresponding MMP gene (Westermarck and Kahari 1999). In relation to the first of them, several studies have identified a wide number of factors able to up-regulate the expression of these enzymes in diverse diseases including cancer. However, the diversity of agents that can mediate MMP production as well as the opposite effects of these factors on the expression of different MMP genes, difficults the selection of the appropriate targets. Nevertheless, recent studies have shown that factors such as IFN- $\alpha$ (interferon- $\alpha$ ), IFN- $\beta$ and IFN- $\gamma$ can be used to inhibit the transcription of several MMPs in diverse human cancer cells (Kuga et al., 2003; Ma et al., 2001; Slaton et al., 2001). Alternatively, different strategies designed for blocking those cytokine-receptor interactions that up-regulate MMP genes have led to interesting results. In fact, several studies have shown that the blockade of TNF- $\alpha$, IL-1 or epithelial growth factor (EGF) receptors reduce MMP production in arthritis or cancer, validating the usefulness of this approach for blocking MMPs (Lal et al., 2002; Mengshol et al., 2002).

A second general approach to abrogate MMP production consists in targeting the signal-transduction pathways that mediate induction of these enzymes. In this regard, the blockade of specific steps in the MAPK pathway leads to the suppression of MMP gene expression in diverse cancer cells. Thus, selective inhibition of p38 MAPK activity with SB203580 abolishes the expression of MMP-1, MMP-9 and MMP-13 in transformed keratinocytes and squamous cell carcinoma 
cells (Johansson et al., 2000; Simon et al., 1998). Likewise, the specific blockade of the ERK pathway has led to MMP downregulation in tumour cells (Pan and Hung 2002; Tanimura et al., 2003). Other compounds such as halofuginone, manumycin $A$, and malolactomycin $D$ also block MMP gene expression through the interference with the TGF- $\beta$ or Ras signalling pathways (Futamura et al., 2001; McGaha et al., 2002; Zhang et al., 2002).

A third option to block MMP up-regulation in human tumours is to target the nuclear factors directly responsible for MMP transcription. Strategies designed to block general factors such as AP-1 and NF- $\mathrm{KB}$ by using glucocorticoids (Karin and Chang 2001) or certain natural products (Aggarwal et al., 2003; Sato et al., 2002; Shishodia et al., 2003; Takada and Aggarwal 2003; Woo et al., 2003a; Woo et al., 2003b), have demonstrated their ability to suppress the production of many MMPs in different cancer types. However, these strategies affect the expression of multiple genes and may have several side effects that could be avoided by targeting more specific factors such as Cbfa1, which selectively modulates the expression of certain MMPs (Jimenez et al., 2001; Yang et al., 2001a). In addition, restoration of the activity of several tumour suppressors such as p53, PTEN, and TEL which are lost in multiple cancers, decreases MMP expression (Fenrick et al., 2000; Koul et al., 2001; Sun et al., 2000). Finally, inhibition of MMP synthesis by antisense-gene transfer constructs (Kondraganti et al., 2000; London et al., 2003), ribozymes (Hua and Muschel 1996), and RNA interference-based approaches (Sanceau et al., 2003; Ueda et al., 2003) represent gene-selective strategies of potential interest for cancer therapy.

\section{Blocking proMMP activation}

MMP gene expression is followed by the participation of multistep proteolytic cascades that finally render the active enzyme. This fact implies that there are several new possibilities of MMP inhibition based on targeting proMMP activation. Several strategies in this regard have been designed to block MT1-MMP, because of its ability to activate proMMPs and also because of its central role in regulating tumour growth (Hotary et al., 2003; Seiki 2003; Sounni et al., 2003). Hence, anti-MT1-MMP monoclonal antibodies, that inhibit its proteolytic activity and impair endothelial cell migration and invasion of collagen and fibrin gels, could be used in future clinical trials (Galvez et al., 2001). MT1-MMP dependent activation of proMMP can also be blocked by natural products such as green-tea catechins (Annabi et al., 2002). Furthermore, the complexity of the enzymatic cascade of MMP activation provides new possibilities to target tumour MMPs by blocking the upstream activators of proMT-MMPs. In this regard, a selective furin inhibitor such as $\alpha 1$-PDX prevents MT1-MMP activation and proMMP-2 processing, with the subsequent attenuation of tumourigenicity and invasiveness of human cancer cells (Bassi et al., 2001). Alternative strategies to block MMP activation are based on the use of thrombospondin-1, which binds to proMMP-2 and proMMP-9 and directly blocks their activation (Bein and Simons 2000; Rodriguez-Manzaneque et al., 2001), or thrombospondin-2, which forms a complex with proMMP-2 and promotes its endocytosis (Yang etal., 2001b). Likewise, endostatin (Kim et al., 2000; Nyberg et al., 2003) and proteoglycans such as testican-3 and N-Tes (Nakada et al., 2001) can suppress proMMP2 activation mediated by MT1-MMP. Finally, protease inhibitors used in human immunodeficiency virus (HIV) therapy are also able to block proMMP-2 activation, thereby contributing to the regression of highly aggressive tumours, such as Kaposi's sarcoma, occurring in HIV patients (Sgadari et al., 2002).

\section{Inhibition of active MMPs \\ Therapeutic potential of TIMPS}

The potential application of TIMPs to block the MMP activity in cancer was initially supported by several studies demonstrating their ability to inhibit tumour growth in transgenic mouse models (Kruger et al., 1997; Martin et al., 1999). However, the possibility of using TIMPs in cancer therapy has technical difficulties, as it happens with other macromolecules (Overall and Lopez-Otin 2002). In addition, recent studies have revealed a series of paradoxical effects of these proteins derived from their ability to perform functions distinct of MMP inhibition. Thus, TIMP-4 up-regulates the anti-apoptotic protein $\mathrm{Bcl}-\mathrm{X}$, thereby stimulating mammary tumourigenesis (Jiang et al., 2001), whereas TIMP-2 shows cell-growth promoting activity (Baker et al., 2002; Jiang et al., 2002). Furthermore, TIMPs are broad-spectrum inhibitors of MMPs and may block the activity of those MMPs that are not necessarily overexpressed in a particular tumour or play protective roles against cancer (Balbin et al., 2003). These observations highlight the need for developing synthetic MMPIs that selectively target specific MMPs.

\section{Synthetic inhibitors and clinical trials}

Although the regulatory mechanisms that control MMP production and activity offer new possibilities for therapeutic intervention, most clinical trials for targeting MMPs have been designed to directly block the proteolytic activity of these enzymes. The first series of synthetic inhibitors were pseudopeptides mimicking the cleavage sites of MMP substrates. They contained a zinc-binding hydroxamate moiety which inhibited MMP activity by specifically interacting with the $\mathrm{Zn}^{2+}$ in the catalytic site. Thus, Batimastat (BB-94), a broadspectrum hydroxamate-based inhibitor, became the first MMPI to be tested in humans (Wojtowicz-Praga et al., 1996). However, clinical trials with intraperitoneally administered Batimastat did not shown any significant responses, and it was replaced by Marimastat (BB2516), another peptido-mimetic MMPI but orally available. Marimastat inhibits the activity of many MMPs including MMP-1, -2, -3, -7, -9, 12 , and -13 . The number of distinct enzymes that this MMPI can target could explain the musculoskeletal pain detected in patients after a sustained treatment with Marimastat (Nemunaitis etal., 1998). Despite this limitation, Marimastat is as effective as conventional therapy (gemcitabine) in treatment of pancreatic carcinoma patients (Bramhall etal., 2001). Furthermore, this inhibitor in combination with temozolomide, improves survival in patients with glioblastoma multiforme (Groves et al., 2002). Lastly, Marimastat can increase survival and time to disease progression in patients with advanced gastric cancer (Bramhall et al., 2002).

Recently, new series of non-peptido mimetics MMPIs with increased specificity and oral bioavailability and based on the 3D structure of MMP zinc-binding sites have been synthesized. Among them, BMS-275291, has special interest due to lack of musculoskeletal side effects and it is currently being evaluated in advanced lung cancer, prostate cancer and AIDS-related Kaposi's sarcoma (Lockhart et al., 2003). In addition, non-peptidic substances with inhibitory properties against MMPs, including tetracycline derivatives and bisphosphonates are being tested in clinical trials (Cianfrocca et al., 2002; Falardeau et al., 2001; Lacerna and Hohneker 2003). In summary, despite initial problems with MMPIs, the stimulating results obtained with marimastat 
are a proof of principle on the clinical value of these compounds for future cancer treatment.

\section{Novel approaches for MMP inhibition}

Taking advantage of the frequent overproduction of MMPs in malignant tumours, novel strategies that exploit the catalytic functions of these enzymes have been recently described for cancer therapy. Some of these approaches involve the generation of protease-activatable retroviral vectors which contain engineered MMPcleavable linkers (Peng et al., 1999; Schneider et al., 2003). Other strategies employ macromolecular carriers that are linked to anticancer drugs released from the carrier by the proteolytic activities of MMPs present in the tumour environment (Mansour et al., 2003). Likewise, Hayashi et al., have designed carriers linked to bioactive molecules that stimulate the antitumour immune response when are liberated by tumour MMPs (Hayashi et al., 2002). Finally, a mutated cytotoxin has been engineered by replacing the furin protease cleavage site that is involved in lethal-factor activation with sequences that are selectively cleaved by MMPs (Liu et al., 2000). The optimization of linker peptides design offers a variety of possibilities for cancer therapy based on expression patterns of MMPs in malignant tumours. Another interesting alternative to synthetic MMPIs is the use of gene therapy approaches aimed at delivering TIMPs at tumour sites (Baker et al., 2002; Zacchigna et al., 2004). However, in addition to the current limitations of gene therapy which include low transfer efficiency and poor specificity of response, the paradoxical effects of TIMPs in cancer may hamper the future clinical application of this approach. On the other hand, it should also be possible to develop innovative strategies for MMP targeting in cancer based on the use of 'exosite blockers'. Protease exosites are substrate-binding sites that lie outside the active-site cleft of the enzyme but are crucial for its proteolytic efficiency (Overall 2002). In the case of MMPs, it should be feasible to design exosite inhibitors that target substratespecific binding sites located in some of the ancillary domains of these proteases (Fig. 1), thereby reducing the binding and cleavage of specific substrates by the corresponding MMP. Likewise, recent experiments have shown that the $\mathrm{C}$-terminal hemopexin domain of MT1-MMP binds native collagen and blocks the collagenolytic activity of both MMP-2 and MT1-MMP (Tam et al., 2002). These findings have opened the possibility of designing substrate-targeted inhibitors that bind the substrate, competing for protease binding at exosites or masking the cleavable peptide bonds. These examples of noncatalytic targeting of MMPs may be part of alternative and innovative strategies aimed at blocking the unwanted activity of these enzymes during tumour progression.

\section{Conclusions and perspectives}

The overproduction of MMPs in cancer has long been correlated with tumour progression and metastasis. Therefore, it is not surprising that over the last years MMPs have been the focus of multiple anticancer trials. The lack of success of most of these clinical trials which were based on using broad-spectrum MMPIs in patients with advanced cancer, has made necessary a reformulation of the role of this proteolytic system in cancer. A series of recent works mainly performed with mouse models of gain and loss of MMP function have provided strong support to the idea that these enzymes play essential roles in early stages of cancer (Fig. 2). These studies have also revealed that certain MMPs can have dual

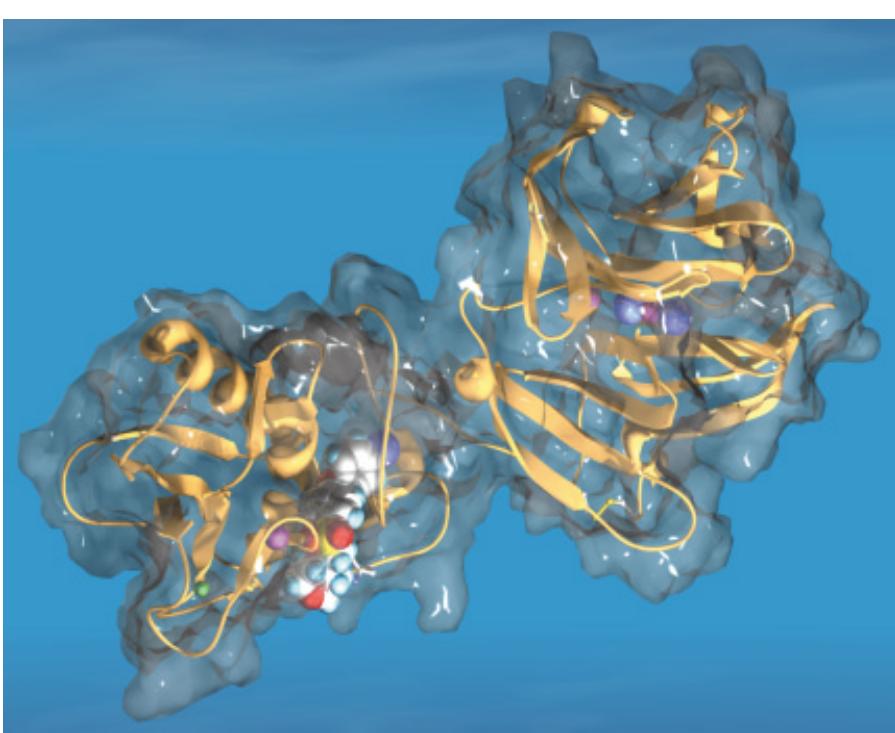

Fig. 3. Structural model of human collagenase-3 bound to a selective inhibitor. The model was created combining the structural data from the catalytic domain (pdb code 830C) and the hemopexin domain (pdb code 1PEX). $\mathrm{Zn}^{2+}$ ions are shown in green, $\mathrm{Ca}^{2+}$ ions in pink, and $\mathrm{Cr}$ ions in blue.

effects on cancer development (Andarawewa et al., 2003) or even favour the host instead of the tumour (Balbin et al., 2003; Hamano et al., 2003; Pozzi et al., 2002). Therefore, broad-spectrum MMPIs may interfere with the natural host defence mechanism against tumours involving bioactive molecule processing by MMPs (Balbin etal., 2003). Moreover, these MMPIs also target proteases such as the ADAMTSs, which have the ability to slow tumour growth through their antiangiogenic activity (Vazquez et al., 1999). Taken together, these findings provide explanations to previous failures of clinical trials with MMPIs (Coussens et al., 2002; Overall and Lopez-Otin 2002; Pavlaki and Zucker 2003), and emphasise the importance of defining the cancer degradome: the complete set of proteases produced by a specific tumour at a certain stage of development (Lopez-Otin and Overall 2002). This concept could be helpful to precisely identify the set of proteases that must be targeted in each specific situation, especially in light of the above mentioned findings demonstrating the occurrence of "protective" enzymes preventing tumour progression (Balbin et al., 2003).

The identification of the specific proteases that must be targeted in cancer should also be correlated with the design of MMPIs that selectively reduce the binding and cleavage of certain substrates by the protease, while not interfering with the cleavage of others. For this purpose, it is essential to increase the number of 3D structures available for these enzymes (Fig. 3), as well as to identify the in vivo substrates that MMPs can target alone or in cooperation with other proteolytic systems and whose hydrolysis may strongly influence the behaviour of tumour cells (Table 2). In addition, a better understanding of the regulatory mechanisms that control MMP transcription, activation and inhibition may offer innovative strategies for targeting MMPs in cancer. These basic studies together with clinical improvements, such as introduction of imaging technologies for in vivo detection of MMPs, identification of surrogate markers of MMP inhibition, and design of appropriate combinations of MMPIs with cytotoxic drugs, may finally lead to effective MMPI-based therapies for cancer. 


\section{Acknowledgements}

We thank Drs. J.M.P. Freije and G. Velasco for helpful comments. The work in our laboratory is supported by grants from CICYT-Spain, Gobierno del Principado de Asturias, Fundación "La Caixa" and European Union (FP5 and FP6-CANCER DEGRADOME). A.R.F. is recipient of a fellowship from Ministerio de Educación y Cultura, Spain. The Instituto Universitario de Oncología is supported by Obra Social Cajastur-Asturias.

\section{References}

AGGARWAL, B. B., KUMAR, A. and BHARTI, A. C. (2003). Anticancer potential of curcumin: preclinical and clinical studies. Anticancer Res. 23: 363-98.

ALEXANDER, C. M., HANSELL, E. J., BEHRENDTSEN, O., FLANNERY, M. L., KISHNANI, N. S., HAWKES, S. P. and WERB, Z. (1996). Expression and function of matrix metalloproteinases and their inhibitors at the maternalembryonic boundary during mouse embryo implantation. Development. 122: 1723-36.

ALEXANDER, C. M., SELVARAJAN, S., MUDGETT, J. and WERB, Z. (2001). Stromelysin-1 regulates adipogenesis during mammary gland involution. J. Cell Biol. 152: 693-703.

AMOUR, A., KNIGHT, C. G., WEBSTER, A., SLOCOMBE, P. M., STEPHENS, P. E., KNAUPER, V., DOCHERTY, A. J. and MURPHY, G. (2000). The in vitro activity of ADAM-10 is inhibited by TIMP-1 and TIMP-3. FEBS Lett. 473: 275-9.

ANDARAWEWA, K. L., BOULAY, A., MASSON, R., MATHELIN, C., STOLL, I., TOMASETTO, C., CHENARD, M. P., GINTZ, M., BELLOCQ, J. P. and RIO, M. C. (2003). Dual stromelysin-3 function during natural mouse mammary tumor virus-ras tumor progression. Cancer Res. 63: 5844-9.

ANNABI, B., LACHAMBRE, M.P., BOUSQUET-GAGNON, N., PAGE, M., GINGRAS, D. and BELIVEAU, R. (2002). Green tea polyphenol (-)-epigallocatechin 3gallate inhibits MMP-2 secretion and MT1-MMP-driven migration in glioblastoma cells. Biochim. Biophys. Acta. 1542: 209-20.

BAKER, A. H., EDWARDS, D. R. and MURPHY, G. (2002). Metalloproteinase inhibitors: biological actions and therapeutic opportunities. J. Cell Sci. 115: 3719-27.

BALBIN, M., FUEYO, A., KNAUPER, V., PENDAS, A. M., LOPEZ, J. M., JIMENEZ, M. G., MURPHY, G. and LOPEZ-OTIN, C. (1998). Collagenase 2 (MMP-8) expression in murine tissue-remodeling processes. Analysis of its potential role in postpartum involution of the uterus. J. Biol. Chem. 273: 23959-68.

BALBIN, M., FUeYO, A., TESTER, A. M., PENDAS, A. M., PITIOT, A. S., ASTUDILLO, A., OVERALL, C. M., SHAPIRO, S. D. and LOPEZ-OTIN, C. (2003). Loss of collagenase-2 confers increased skin tumor susceptibility to male mice. Nat. Genet. 35: 252-7.

BANNIKOV, G. A., KARELINA, T. V., COLLIER, I. E., MARMER, B. L. and GOLDBERG, G. I. (2002). Substrate binding of gelatinase B induces its enzymatic activity in the presence of intact propeptide. J. Biol. Chem. 277: 16022-7.

BASSI, D. E., LOPEZ DE CICCO, R., MAHLOOGI, H., ZUCKER, S., THOMAS, G. and KLEIN-SZANTO, A. J. (2001). Furin inhibition results in absent or decreased invasiveness and tumorigenicity of human cancer cells. Proc. Natl. Acad. Sci. USA. 98: 10326-31.

BEARE, A. H., O'KANE, S., KRANE, S. M. and FERGUSON, M. W. (2003). Severely impaired wound healing in the collagenase-resistant mouse. J. Invest. Dermatol. 120: 153-63.

BEIN, K. and SIMONS, M. (2000). Thrombospondin type 1 repeats interact with matrix metalloproteinase 2. Regulation of metalloproteinase activity. J. Biol. Chem. 275: 32167-73.

BELOTTI, D., PAGANONI, P., MANENTI, L., GAROFALO, A., MARCHINI, S., TARABOLETTI, G. and GIAVAZZI, R. (2003). Matrix metalloproteinases (MMP9 and MMP2) induce the release of vascular endothelial growth factor (VEGF) by ovarian carcinoma cells: implications for ascites formation. Cancer Res. 63: 5224-9.

BERGERS, G., BREKKEN, R., MCMAHON, G., VU, T. H., ITOH, T., TAMAKI, K., TANZAWA, K., THORPE, P., ITOHARA, S., WERB, Z. and HANAHAN, D. (2000). Matrix metalloproteinase-9 triggers the angiogenic switch during carcinogenesis. Nat. Cell Biol. 2: 737-44.

BODE, W. (2003). Structural basis of matrix metalloproteinase function. Biochem. Soc. Symp. 1-14.
BOND, M., FABUNMI, R. P., BAKER, A. H. and NEWBY, A. C. (1998). Synergistic upregulation of metalloproteinase- 9 by growth factors and inflammatory cytokines: an absolute requirement for transcription factor NF-kappa B. FEBS Lett. 435: 2934.

BOULAY, A., MASSON, R., CHENARD, M. P., EL FAHIME, M., CASSARD, L., BELLOCQ, J. P., SAUTES-FRIDMAN, C., BASSET, P. and RIO, M. C. (2001). High cancer cell death in syngeneic tumors developed in host mice deficient for the stromelysin-3 matrix metalloproteinase. Cancer Res. 61: 2189-93.

BOULOUMIE, A., SENGENES, C., PORTOLAN, G., GALITZKY, J. and LAFONTAN, M. (2001). Adipocyte produces matrix metalloproteinases 2 and 9: involvement in adipose differentiation. Diabetes. 50: 2080-6.

BRAMHALL, S. R., HALLISSEY, M. T., WHITING, J., SCHOLEFIELD, J., TIERNEY, G., STUART, R. C., HAWKINS, R. E., MCCULLOCH, P., MAUGHAN, T., BROWN, P. D., BAILLET, M. and FIELDING, J. W. (2002). Marimastat as maintenance therapy for patients with advanced gastric cancer: a randomised trial. $B r . J$ Cancer. 86: 1864-70.

BRAMHALL, S. R., ROSEMURGY, A., BROWN, P. D., BOWRY, C. and BUCKELS, J. A. (2001). Marimastat as first-line therapy for patients with unresectable pancreatic cancer: a randomized trial. J. Clin. Oncol. 19: 3447-55.

BREW, K., DINAKARPANDIAN, D. and NAGASE, H. (2000). Tissue inhibitors of metalloproteinases: evolution, structure and function. Biochim. Biophys. Acta. 1477: $267-83$

BRINCKERHOFF, C. E. and MATRISIAN, L. M. (2002). Matrix metalloproteinases: a tail of a frog that became a prince. Nat. Rev. Mol. Cell Biol. 3: 207-14.

BROOKS, P. C., CLARK, R. A. and CHERESH, D. A. (1994). Requirement of vascular integrin alpha $v$ beta 3 for angiogenesis. Science. 264: 569-71.

BULLARD, K. M., LUND, L., MUDGETT, J. S., MELLIN, T. N., HUNT, T. K., MURPHY, B., RONAN, J., WERB, Z. and BANDA, M. J. (1999). Impaired wound contraction in stromelysin-1-deficient mice. Ann. Surg. 230: 260-5.

CHAMBERS, A. F., GROOM, A. C. and MACDONALD, I. C. (2002). Dissemination and growth of cancer cells in metastatic sites. Nat. Rev. Cancer. 2: 563-72.

CIANFROCCA, M., COOLEY, T. P., LEE, J. Y., RUDEK, M. A., SCADDEN, D. T., RATNER, L., PLUDA, J. M., FIGG, W. D., KROWN, S. E. and DEZUBE, B. J. (2002). Matrix metalloproteinase inhibitor COL-3 in the treatment of AIDS-related Kaposi's sarcoma: a phase I AIDS malignancy consortium study. J. Clin. Oncol. 20: 153-9.

CORNELIUS, L. A., NEHRING, L. C., HARDING, E., BOLANOWSKI, M., WELGUS H. G., KOBAYASHI, D. K., PIERCE, R. A. and SHAPIRO, S. D. (1998). Matrix metalloproteinases generate angiostatin: effects on neovascularization. J. Immunol. 161: $6845-52$

COUSSENS, L. M., FINGLETON, B. and MATRISIAN, L. M. (2002). Matrix metalloproteinase inhibitors and cancer: trials and tribulations. Science. 295: 2387-92.

COUSSENS, L. M., TINKLE, C. L., HANAHAN, D. and WERB, Z. (2000). MMP-9 supplied by bone marrow-derived cells contributes to skin carcinogenesis. Cell. 103: 481-90.

COUSSENS, L. M. and WERB, Z. (2002). Inflammation and cancer. Nature. 420: 8607.

CRAWFORD, H. C., FINGLETON, B., GUSTAVSON, M. D., KURPIOS, N., WAGENAAR, R. A., HASSELL, J. A. and MATRISIAN, L. M. (2001). The PEA3 subfamily of Ets transcription factors synergizes with beta-catenin-LEF-1 to activate matrilysin transcription in intestinal tumors. Mol. Cell Biol. 21: 1370-83.

CUKIERMAN, E., PANKOV, R., STEVENS, D. R. and YAMADA, K. M. (2001). Taking cell-matrix adhesions to the third dimension. Science. 294: 1708-12.

CURRY, T. E., JR. and OSTEEN, K. G. (2003). The matrix metalloproteinase system: changes, regulation, and impact throughout the ovarian and uterine reproductive cycle. Endocr. Rev. 24: 428-65.

DE WEVER, O. and MAREEL, M. (2003). Role of tissue stroma in cancer cell invasion. J. Pathol. 200: 429-47.

DECLERCK, Y. A. and IMREN, S. (1994). Protease inhibitors: role and potential therapeutic use in human cancer. Eur. J. Cancer. 30A: 2170-80.

EGEBLAD, M. and WERB, Z. (2002). New functions for the matrix metalloproteinases in cancer progression. Nat. Rev. Cancer. 2: 161-74.

FALARDEAU, P., CHAMPAGNE, P., POYET, P., HARITON, C. and DUPONT, E. (2001). Neovastat, a naturally occurring multifunctional antiangiogenic drug, in phase III clinical trials. Semin. Oncol. 28: 620-5. 
FENRICK, R., WANG, L., NIP, J., AMANN, J. M., ROONEY, R. J., WALKER-DANIELS, J., CRAWFORD, H. C., HULBOY, D. L., KINCH, M. S., MATRISIAN, L. M. and HIEBERT, S. W. (2000). TEL, a putative tumor suppressor, modulates cell growth and cell morphology of ras-transformed cells while repressing the transcription of stromelysin-1. Mol. Cell. Biol. 20: 5828-39.

FERRERAS, M., FELBOR, U., LENHARD, T., OLSEN, B. R. and DELAISSE, J. (2000). Generation and degradation of human endostatin proteins by various proteinases. FEBS Lett. 486: 247-51.

FREIJE, J. M., BALBIN, M., PENDAS, A. M., SANCHEZ, L. M., PUENTE, X. S. and LOPEZ-OTIN, C. (2003). Matrix metalloproteinases and tumor progression. Adv. Exp. Med. Biol. 532: 91-107.

FUTAMURA, M., KAMIYA, S., TSUKAMOTO, M., HIRANO, A., MONDEN, Y., ARAKAWA, H. and NISHIMURA, S. (2001). Malolactomycin D, a potent inhibitor of transcription controlled by the Ras responsive element, inhibits Ras-mediated transformation activity with suppression of MMP-1 and MMP-9 in NIH3T3 cells. Oncogene. 20: 6724-30

GALVEZ, B. G., MATIAS-ROMAN, S., ALBAR, J. P., SANCHEZ-MADRID, F. and ARROYO, A. G. (2001). Membrane type 1-matrix metalloproteinase is activated during migration of human endothelial cells and modulates endothelial motility and matrix remodeling. J. Biol. Chem. 276: 37491-500.

GHILARDI, G., BIONDI, M. L., CAPUTO, M., LEVITI, S., DEMONTI, M., GUAGNELLINI, E. and SCORZA, R. (2002). A single nucleotide polymorphism in the matrix metalloproteinase-3 promoter enhances breast cancer susceptibility. Clin. Cancer Res. 8: 3820-3.

GHILARDI, G., BIONDI, M. L., ERARIO, M., GUAGNELLINI, E. and SCORZA, R. (2003). Colorectal carcinoma susceptibility and metastases are associated with matrix metalloproteinase-7 promoter polymorphisms. Clin. Chem. 49: 1940-2.

GOMIS-RUTH, F. X., MASKOS, K., BETZ, M., BERGNER, A., HUBER, R., SUZUKI, K., YOSHIDA, N., NAGASE, H., BREW, K., BOURENKOV, G. P., BARTUNIK, H. and BODE, W. (1997). Mechanism of inhibition of the human matrix metalloproteinase stromelysin-1 by TIMP-1. Nature. 389: 77-81.

GROSS, J. and LAPIERE, C. M. (1962). Collagenolytic activity in amphibian tissues: a tissue culture assay. Proc. Natl. Acad. Sci. USA. 48: 1014-22.

GROVES, M. D., PUDUVALLI, V. K., HESS, K. R., JAECKLE, K. A., PETERSON, P., YUNG, W. K. and LEVIN, V. A. (2002). Phase II trial of temozolomide plus the matrix metalloproteinase inhibitor, marimastat, in recurrent and progressive glioblastoma multiforme. J. Clin. Oncol. 20: 1383-8.

GU, Z., KAUL, M., YAN, B., KRIDEL, S. J., CUI, J., STRONGIN, A., SMITH, J. W., LIDDINGTON, R. C. and LIPTON, S. A. (2002). S-nitrosylation of matrix metalloproteinases: signaling pathway to neuronal cell death. Science. 297: 118690

GUERIN, E., LUDWIG, M. G., BASSET, P. and ANGLARD, P. (1997). Stromelysin-3 induction and interstitial collagenase repression by retinoic acid. Therapeutical implication of receptor-selective retinoids dissociating transactivation and AP-1mediated transrepression. J. Biol. Chem. 272: 11088-95.

HAGGLUND, A. C., NY, A., LEONARDSSON, G. and NY, T. (1999). Regulation and localization of matrix metalloproteinases and tissue inhibitors of metalloproteinases in the mouse ovary during gonadotropin-induced ovulation. Endocrinology. 140: 4351-8.

HAMANO, Y., ZEISBERG, M., SUGIMOTO, H., LIVELY, J. C., MAESHIMA, Y., YANG, C., HYNES, R. O., WERB, Z., SUDHAKAR, A. and KALLURI, R. (2003). Physiological levels of tumstatin, a fragment of collagen IV alpha3 chain, are generated by MMP-9 proteolysis and suppress angiogenesis via alphaV beta3 integrin. Cancer Cell. 3: 589-601.

HAYASHI, M., TOMITA, M. and YOSHIZATO, K. (2002). Interleukin-2-collagen chimeric protein which liberates interleukin-2 upon collagenolysis. Protein Eng. 15: 429-36.

HERMAN, M. P., SUKHOVA, G. K., KISIEL, W., FOSTER, D., KEHRY, M. R., LIBBY, $P$. and SCHONBECK, U. (2001). Tissue factor pathway inhibitor-2 is a nove inhibitor of matrix metalloproteinases with implications for atherosclerosis. J. Clin. Invest. 107: 1117-26.

HIRAOKA, N., ALLEN, E., APEL, I. J., GYETKO, M. R. and WEISS, S. J. (1998). Matrix metalloproteinases regulate neovascularization by acting as pericellular fibrinolysins. Cell. 95: 365-77.

HIRATSUKA, S., NAKAMURA, K., IWAI, S., MURAKAMI, M., ITOH, T., KIJIMA, H., SHIPLEY, J. M., SENIOR, R. M. and SHIBUYA, M. (2002). MMP9 induction by vascular endothelial growth factor receptor- 1 is involved in lung-specific metastasis. Cancer Cell. 2: 289-300.
HOJILLA, C. V., MOHAMMED, F. F. and KHOKHA, R. (2003). Matrix metalloproteinases and their tissue inhibitors direct cell fate during cancer development. Br. J. Cancer 89: 1817-21.

HOLMBECK, K., BIANCO, P., CATERINA, J., YAMADA, S., KROMER, M. KUZNETSOV, S. A., MANKANI, M., ROBEY, P. G., POOLE, A. R., PIDOUX, I., WARD, J. M. and BIRKEDAL-HANSEN, H. (1999). MT1-MMP-deficient mice develop dwarfism, osteopenia, arthritis, and connective tissue disease due to inadequate collagen turnover. Cell. 99: 81-92.

HOTARY, K. B., ALLEN, E. D., BROOKS, P. C., DATTA, N. S., LONG, M. W. and WEISS, S. J. (2003). Membrane type I matrix metalloproteinase usurps tumor growth control imposed by the three-dimensional extracellular matrix. Cell. 114: 33-45

HUA, J. and MUSCHEL, R. J. (1996). Inhibition of matrix metalloproteinase 9 expression by a ribozyme blocks metastasis in a rat sarcoma model system. Cancer Res. 56: 5279-84.

HUANG, S., VAN ARSDALL, M., TEDJARATI, S., MCCARTY, M., WU, W., LAN GLEY, R. and FIDLER, I. J. (2002). Contributions of stromal metalloproteinase-9 to angiogenesis and growth of human ovarian carcinoma in mice. J. Natl. Cancer Inst. 94: 1134-42.

HULBOY, D. L., RUDOLPH, L. A. and MATRISIAN, L. M. (1997). Matrix metalloproteinases as mediators of reproductive function. Mol. Hum. Reprod. 3 27-45.

ITOH, T., TANIOKA, M., YOSHIDA, H., YOSHIOKA, T., NISHIMOTO, H. and ITOHARA, S. (1998). Reduced angiogenesis and tumor progression in gelatinase A-deficient mice. Cancer Res. 58: 1048-51.

JIANG, Y., GOLDBERG, I. D. and SHI, Y. E. (2002). Complex roles of tissue inhibitors of metalloproteinases in cancer. Oncogene. 21: 2245-52.

JIANG, Y., WANG, M., CELIKER, M. Y., LIU, Y. E., SANG, Q. X., GOLDBERG, I. D. and SHI, Y. E. (2001). Stimulation of mammary tumorigenesis by systemic tissue inhibitor of matrix metalloproteinase 4 gene delivery. Cancer Res. 61: 2365-70.

JIMENEZ, M. J., BALBIN, M., ALVAREZ, J., KOMORI, T., BIANCO, P., HOLMBECK, K., BIRKEDAL-HANSEN, H., LOPEZ, J. M. and LOPEZ-OTIN, C. (2001). A regulatory cascade involving retinoic acid, $\mathrm{Cbfa1}$, and matrix metalloproteinases is coupled to the development of a process of perichondrial invasion and osteogenic differentiation during bone formation. J. Cell Biol. 155: 1333-44.

JOHANSSON, N., ALA-AHO, R., UITTO, V., GRENMAN, R., FUSENIG, N. E., LOPEZ-OTIN, C. and KAHARI, V. M. (2000). Expression of collagenase-3 (MMP13) and collagenase-1 (MMP-1) by transformed keratinocytes is dependent on the activity of p38 mitogen-activated protein kinase. J. Cell Sci. 113 Pt 2: 227-35.

KARIN, M. and CHANG, L. (2001). AP-1-glucocorticoid receptor crosstalk taken to a higher level. J. Endocrinol. 169: 447-51.

KASHIWAGI, M., TORTORELLA, M., NAGASE, H. and BREW, K. (2001). TIMP-3 is a potent inhibitor of aggrecanase 1 (ADAM-TS4) and aggrecanase 2 (ADAM-TS5) J. Biol. Chem. 276: 12501-4.

KATAOKA, H., UCHINO, H., IWAMURA, T., SEIKI, M., NABESHIMA, K. and KOONO, M. (1999). Enhanced tumor growth and invasiveness in vivoby a carboxyl-terminal fragment of alpha1-proteinase inhibitor generated by matrix metalloproteinases: a possible modulatory role in natural killer cytotoxicity. Am. J. Pathol. 154: 457-68.

KHOKHA, R., WATERHOUSE, P., YAGEL, S., LALA, P. K., OVERALL, C. M., NORTON, G. and DENHARDT, D. T. (1989). Antisense RNA-induced reduction in murine TIMP levels confers oncogenicity on Swiss 3T3 cells. Science. 243: 947-50.

KIM, Y. M., JANG, J. W., LEE, O. H., YEON, J., CHOI, E. Y., KIM, K. W., LEE, S. T. and KWON, Y. G. (2000). Endostatin inhibits endothelial and tumor cellular invasion by blocking the activation and catalytic activity of matrix metalloproteinase. Cancer Res. 60: 5410-3.

KONDRAGANTI, S., MOHANAM, S., CHINTALA, S. K., KIN, Y., JASTI, S. L.' NIRMALA, C., LAKKA, S. S., ADACHI, Y., KYRITSIS, A. P., ALI-OSMAN, F., SAWAYA, R., FULLER, G. N. and RAO, J. S. (2000). Selective suppression of matrix metalloproteinase- 9 in human glioblastoma cells by antisense gene transfer impairs glioblastoma cell invasion. Cancer Res. 60: 6851-5.

KOUL, D., PARTHASARATHY, R., SHEN, R., DAVIES, M. A., JASSER, S. A., CHINTALA, S. K., RAO, J. S., SUN, Y., BENVENISITE, E. N., LIU, T. J. and YUNG, W. K. (2001). Suppression of matrix metalloproteinase-2 gene expression and invasion in human glioma cells by MMAC/PTEN. Oncogene. 20: 6669-78.

KRUGER, A., FATA, J. E. and KHOKHA, R. (1997). Altered tumor growth and metastasis of a T-cell lymphoma in Timp-1 transgenic mice. Blood. 90: 1993-2000 
KUGA, H., MORISAKI, T., NAKAMURA, K., ONISHI, H., NOSHIRO, H., UCHIYAMA, A., TANAKA, M. and KATANO, M. (2003). Interferon-gamma suppresses transforming growth factor-beta-induced invasion of gastric carcinoma cells through cross-talk of Smad pathway in a three-dimensional culture model. Oncogene. 22: 7838-47.

LACERNA, L. and HOHNEKER, J. (2003). Zoledronic acid for the treatment of bone metastases in patients with breast cancer and other solid tumors. Semin. Oncol. 30: 150-60.

LAL, A., GLAZER, C. A., MARTINSON, H. M., FRIEDMAN, H. S., ARCHER, G. E., SAMPSON, J. H. and RIGGINS, G. J. (2002). Mutant epidermal growth factor receptor up-regulates molecular effectors of tumor invasion. Cancer Res. 62: 3335-9.

LAMBERT, V., WIELOCKX, B., MUNAUT, C., GALOPIN, C., JOST, M., ITOH, T., WERB, Z., BAKER, A., LIBERT, C., KRELL, H. W., FOIDART, J. M., NOEL, A. and RAKIC, J. M. (2003). MMP-2 and MMP-9 synergize in promoting choroidal neovascularization. FASEB J. 17: 2290-2.

LEE, M. H., RAPTI, M. and MURPHY, G. (2003). Unveiling the surface epitopes that render tissue inhibitor of metalloproteinase-1 inactive against membrane type 1matrix metalloproteinase. J. Biol. Chem. 278: 40224-30.

LEE, S. J., JANG, J. W., KIM, Y. M., LEE, H. I., JEON, J. Y., KWON, Y. G. and LEE, S. T. (2002). Endostatin binds to the catalytic domain of matrix metalloproteinase-2. FEBS Lett. 519: 147-52.

LI, Q., PARK, P. W., WILSON, C. L. and PARKS, W. C. (2002). Matrilysin shedding of syndecan-1 regulates chemokine mobilization and transepithelial efflux of neutrophils in acute lung injury. Cell. 111: 635-46.

LIJNEN, H. R. (2001). Plasmin and matrix metalloproteinases in vascular remodeling. Thromb. Haemost. 86: 324-33.

LIU, L. T., CHANG, H. C., CHIANG, L. C. and HUNG, W. C. (2003). Histone deacetylase inhibitor up-regulates RECK to inhibit MMP-2 activation and cancer cell invasion. Cancer Res. 63: 3069-72.

LIU, S., NETZEL-ARNETT, S., BIRKEDAL-HANSEN, H. and LEPPLA, S. H. (2000). Tumor cell-selective cytotoxicity of matrix metalloproteinase-activated anthrax toxin. Cancer Res. 60: 6061-7.

LLANO, E., ADAM, G., PENDAS, A. M., QUESADA, V., SANCHEZ, L. M., SANTAMARIA, I., NOSELLI, S. and LOPEZ-OTIN, C. (2002). Structural and enzymatic characterization of Drosophila Dm2-MMP, a membrane-bound matrix metalloproteinase with tissue-specific expression. J. Biol. Chem. 277: 23321-9.

LLANO, E., PENDAS, A. M., AZA-BLANC, P., KORNBERG, T. B. and LOPEZ-OTIN, C. (2000). Dm1-MMP, a matrix metalloproteinase from Drosophila with a potential role in extracellular matrix remodeling during neural development. J. Biol. Chem. 275: 35978-85.

LOCKHART, A. C., BRAUN, R. D., YU, D., ROSS, J. R., DEWHIRST, M. W., HUMPHREY, J. S., THOMPSON, S., WILLIAMS, K. M., KLITZMAN, B., YUAN, F., GRICHNIK, J. M., PROIA, A. D., CONWAY, D. A. and HURWITZ, H. I. (2003). Reduction of wound angiogenesis in patients treated with BMS-275291, a broad spectrum matrix metalloproteinase inhibitor. Clin. Cancer Res. 9: 586-93.

LOHI, J., WILSON, C. L., ROBY, J. D. and PARKS, W. C. (2001). Epilysin, a novel human matrix metalloproteinase (MMP-28) expressed in testis and keratinocytes and in response to injury. J. Biol. Chem. 276: 10134-44.

LONDON, C. A., SEKHON, H. S., ARORA, V., STEIN, D. A., IVERSEN, P. L. and DEVI, G. R. (2003). A novel antisense inhibitor of MMP-9 attenuates angiogenesis, human prostate cancer cell invasion and tumorigenicity. Cancer Gene Ther. 10: 823-32.

LOPEZ-OTIN, C. and OVERALL, C. M. (2002). Protease degradomics: a new challenge for proteomics. Nat. Rev. Mol. Cell Biol. 3: 509-19.

LUND, L. R., ROMER, J., BUGGE, T. H., NIELSEN, B. S., FRANDSEN, T. L., DEGEN, J. L., STEPHENS, R. W. and DANO, K. (1999). Functional overlap between two classes of matrix-degrading proteases in wound healing. EMBO J. 18: 4645-56.

MA, Z., QIN, H. and BENVENISTE, E. N. (2001). Transcriptional suppression of matrix metalloproteinase- 9 gene expression by IFN-gamma and IFN-beta: critical role of STAT-1alpha. J. Immunol. 167: 5150-9.

MANES, S., MIRA, E., BARBACID, M. M., CIPRES, A., FERNANDEZ-RESA, P., BUESA, J. M., MERIDA, I., ARACIL, M., MARQUEZ, G. and MARTINEZ, A. C. (1997). Identification of insulin-like growth factor-binding protein-1 as a potential physiological substrate for human stromelysin-3. J. Biol. Chem. 272: 25706-12.

MANSOUR, A. M., DREVS, J., ESSER, N., HAMADA, F. M., BADARY, O. A., UNGER, C., FICHTNER, I. and KRATZ, F. (2003). A new approach for the treatment of malignant melanoma: enhanced antitumor efficacy of an albumin-binding doxorubicin prodrug that is cleaved by matrix metalloproteinase 2. Cancer Res. 63: 4062-6.
MAREEL, M. and LEROY, A. (2003). Clinical, cellular, and molecular aspects of cancer invasion. Physiol. Rev. 83: 337-76.

MARTIN, D. C., SANCHEZ-SWEATMAN, O. H., HO, A. T., INDERDEO, D. S., TSAO, M. S. and KHOKHA, R. (1999). Transgenic TIMP-1 inhibits simian virus $40 \mathrm{~T}$ antigen-induced hepatocarcinogenesis by impairment of hepatocellular proliferation and tumor angiogenesis. Lab. Invest. 79: 225-34.

MCGAHA, T. L., PHELPS, R. G., SPIERA, H. and BONA, C. (2002). Halofuginone, an inhibitor of type-I collagen synthesis and skin sclerosis, blocks transforminggrowth-factor-beta-mediated Smad3 activation in fibroblasts. J. Invest. Dermatol. 118: $461-70$

MCQUIBBAN, G. A., GONG, J. H., TAM, E. M., MCCULLOCH, C. A., CLARK-LEWIS, I. and OVERALL, C. M. (2000). Inflammation dampened by gelatinase A cleavage of monocyte chemoattractant protein-3. Science. 289: 1202-6.

MENGSHOL, J. A., MIX, K. S. and BRINCKERHOFF, C. E. (2002). Matrix metalloproteinases as therapeutic targets in arthritic diseases: bull's-eye or missing the mark?. Arthritis Rheum. 46: 13-20.

MIAO, X., YU, C., TAN, W., XIONG, P., LIANG, G., LU, W. and LIN, D. (2003). A functional polymorphism in the matrix metalloproteinase-2 gene promoter (-1306C/ $\mathrm{T})$ is associated with risk of development but not metastasis of gastric cardia adenocarcinoma. Cancer Res. 63: 3987-90.

MITSIADES, N., YU, W. H., POULAKI, V., TSOKOS, M. and STAMENKOVIC, I. (2001) Matrix metalloproteinase-7-mediated cleavage of Fas ligand protects tumor cells from chemotherapeutic drug cytotoxicity. Cancer Res. 61: 577-81.

MOHAN, R., SIVAK, J., ASHTON, P., RUSSO, L. A., PHAM, B. Q., KASAHARA, N., RAIZMAN, M. B. and FINI, M. E. (2000). Curcuminoids inhibit the angiogenic response stimulated by fibroblast growth factor-2, including expression of matrix metalloproteinase gelatinase B. J. Biol. Chem. 275: 10405-12.

MORGUNOVA, E., TUUTTILA, A., BERGMANN, U., ISUPOV, M., LINDQVIST, Y., SCHNEIDER, G. and TRYGGVASON, K. (1999). Structure of human pro-matrix metalloproteinase-2: activation mechanism revealed. Science. 284: 1667-70.

MORRISON, C. J., BUTLER, G. S., BIGG, H. F., ROBERTS, C. R., SOLOWAY, P. D. and OVERALL, C. M. (2001). Cellular activation of MMP-2 (gelatinase A) by MT2MMP occurs via a TIMP-2-independent pathway. J. Biol. Chem. 276: 47402-10.

MOTT, J. D., THOMAS, C. L., ROSENBACH, M. T., TAKAHARA, K., GREENSPAN, D. S. and BANDA, M. J. (2000). Post-translational proteolytic processing of procollagen C-terminal proteinase enhancer releases a metalloproteinase inhibitor. J. Biol. Chem. 275: 1384-90.

NAGASE, H. (1997). Activation mechanisms of matrix metalloproteinases. Biol. Chem. 378: 151-60.

NAKADA, M., YAMADA, A., TAKINO, T., MIYAMORI, H., TAKAHASHI, T., YAMASHITA, J. and SATO, H. (2001). Suppression of membrane-type 1 matrix metalloproteinase (MMP)-mediated MMP-2 activation and tumor invasion by testican 3 and its splicing variant gene product, N-Tes. Cancer Res. 61: 8896-902.

NEMUNAITIS, J., POOLE, C., PRIMROSE, J., ROSEMURGY, A., MALFETANO, J., BROWN, P., BERRINGTON, A., CORNISH, A., LYNCH, K., RASMUSSEN, H., KERR, D., COX, D. and MILLAR, A. (1998). Combined analysis of studies of the effects of the matrix metalloproteinase inhibitor marimastat on serum tumor markers in advanced cancer: selection of a biologically active and tolerable dose for longerterm studies. Clin. Cancer Res. 4: 1101-9.

NIE, J. and PEI, D. (2003). Direct activation of pro-matrix metalloproteinase-2 by leukolysin/membrane-type 6 matrix metalloproteinase/matrix metalloproteinase 25 at the asn(109)-Tyr bond. Cancer Res. 63: 6758-62.

NIELSEN, B. S., RANK, F., LOPEZ, J. M., BALBIN, M., VIZOSO, F., LUND, L. R. DANO, K. and LOPEZ-OTIN, C. (2001). Collagenase-3 expression in breast myofibroblasts as a molecular marker of transition of ductal carcinoma in situ lesions to invasive ductal carcinomas. Cancer Res. 61: 7091-100.

NY, T., WAHLBERG, P. and BRANDSTROM, I. J. (2002). Matrix remodeling in the ovary: regulation and functional role of the plasminogen activator and matrix metalloproteinase systems. Mol. Cell. Endocrinol. 187: 29-38.

NYBERG, P., HEIKKILA, P., SORSA, T., LUOSTARINEN, J., HELJASVAARA, R., STENMAN, U. H., PIHLAJANIEMI, T. and SALO, T. (2003). Endostatin inhibits human tongue carcinoma cell invasion and intravasation and blocks the activation of matrix metalloprotease-2, -9, and -13. J. Biol. Chem. 278: 22404-11.

OH, J., TAKAHASHI, R., KONDO, S., MIZOGUCHI, A., ADACHI, E., SASAHARA, R. M., NISHIMURA, S., IMAMURA, Y., KITAYAMA, H., ALEXANDER, D. B., IDE, C., HORAN, T. P., ARAKAWA, T., YOSHIDA, H., NISHIKAWA, S., ITOH, Y., SEIKI, M., ITOHARA, S., TAKAHASHI, C. and NODA, M. (2001). The membrane-anchored MMP inhibitor RECK is a key regulator of extracellular matrix integrity and angiogenesis. Cell. 107: 789-800. 
OVERALL, C. M. (2002). Molecular determinants of metalloproteinase substrate specificity: matrix metalloproteinase substrate binding domains, modules, and exosites. Mol. Biotechnol. 22: 51-86.

OVERALL, C. M. and LOPEZ-OTIN, C. (2002). Strategies for MMP inhibition in cancer: innovations for the post-trial era. Nat. Rev. Cancer. 2: 657-72.

OVERALL, C. M., WRANA, J. L. and SODEK, J. (1989). Independent regulation of collagenase, 72-kDa progelatinase, and metalloendoproteinase inhibitor expression in human fibroblasts by transforming growth factor-beta. J. Biol. Chem. 264: 1860-9

PAGE-MCCAW, A., SERANO, J., SANTE, J. M. and RUBIN, G. M. (2003). Drosophila matrix metalloproteinases are required for tissue remodeling, but not embryonic development. Dev. Cell. 4: 95-106.

PAN, M. R. and HUNG, W. C. (2002). Nonsteroidal anti-inflammatory drugs inhibit matrix metalloproteinase-2 via suppression of the ERK/Sp1-mediated transcription. J. Biol. Chem. 277: 32775-80.

PAVLAKI, M. and ZUCKER, S. (2003). Matrix metalloproteinase inhibitors (MMPIs): the beginning of phase I or the termination of phase III clinical trials. Cancer Metastasis Rev. 22: 177-203.

PEI, D., KANG, T. and QI, H. (2000). Cysteine array matrix metalloproteinase (CAMMP)/MMP-23 is a type II transmembrane matrix metalloproteinase regulated by a single cleavage for both secretion and activation. J. Biol. Chem. 275: 33988-97.

PEI, D. and WEISS, S. J. (1995). Furin-dependent intracellular activation of the human stromelysin-3 zymogen. Nature. 375: 244-7.

PENDAS, A. M., BALBIN, M., LLANO, E., JIMENEZ, M. G. and LOPEZ-OTIN, C. (1997). Structural analysis and promoter characterization of the human collagenase-3 gene (MMP13). Genomics. 40: 222-33.

PENG, K. W., VILE, R., COSSET, F. L. and RUSSELL, S. (1999). Selective transduction of protease-rich tumors by matrix-metalloproteinase-targeted retroviral vectors. Gene Ther. 6: 1552-7.

PETITCLERC, E., BOUTAUD, A., PRESTAYKO, A., XU, J., SADO, Y., NINOMIYA, Y., SARRAS, M. P., JR., HUDSON, B. G. and BROOKS, P. C. (2000). New functions for non-collagenous domains of human collagen type IV. Novel integrin ligands inhibiting angiogenesis and tumor growth in vivo. J. Biol. Chem. 275: 8051-61.

PILCHER, B. K., DUMIN, J. A., SUDBECK, B. D., KRANE, S. M., WELGUS, H. G. and PARKS, W. C. (1997). The activity of collagenase-1 is required for keratinocyte migration on a type I collagen matrix. J. Cell Biol. 137: 1445-57.

POWELL, W. C., FINGLETON, B., WILSON, C. L., BOOTHBY, M. and MATRISIAN, L. M. (1999). The metalloproteinase matrilysin proteolytically generates active soluble Fas ligand and potentiates epithelial cell apoptosis. Curr. Biol. 9: 1441-7.

POZZI, A., LEVINE, W. F. and GARDNER, H. A. (2002). Low plasma levels of matrix metalloproteinase 9 permit increased tumor angiogenesis. Oncogene. 21: 27281.

PUENTE, X. S., SANCHEZ, L. M., OVERALL, C. M. and LOPEZ-OTIN, C. (2003). Human and mouse proteases: a comparative genomic approach. Nat. Rev. Genet. 4: 544-58.

QI, J. H., EBRAHEM, Q., MOORE, N., MURPHY, G., CLAESSON-WELSH, L., BOND, M., BAKER, A. and ANAND-APTE, B. (2003). A novel function for tissue inhibitor of metalloproteinases-3 (TIMP3): inhibition of angiogenesis by blockage of VEGF binding to VEGF receptor-2. Nat. Med. 9: 407-15.

REUNANEN, N., LI, S. P., AHONEN, M., FOSCHI, M., HAN, J. and KAHARI, V. M. (2002). Activation of p38 alpha MAPK enhances collagenase-1 (matrix metalloproteinase (MMP)-1) and stromelysin-1 (MMP-3) expression by mRNA stabilization. J. Biol. Chem. 277: 32360-8

RODRIGUEZ-MANZANEQUE, J. C., LANE, T. F., ORTEGA, M. A., HYNES, R. O., LAWLER, J. and IRUELA-ARISPE, M. L. (2001). Thrombospondin-1 suppresses spontaneous tumor growth and inhibits activation of matrix metalloproteinase-9 and mobilization of vascular endothelial growth factor. Proc. Natl. Acad. Sci. U. S. A. 98: 12485-90.

RUDOLPH-OWEN, L. A., HULBOY, D. L., WILSON, C. L., MUDGETT, J. and MATRISIAN, L. M. (1997). Coordinate expression of matrix metalloproteinase family members in the uterus of normal, matrilysin-deficient, and stromelysin-1deficient mice. Endocrinology. 138: 4902-11.

RUHUL AMIN, A. R., OO, M. L., SENGA, T., SUZUKI, N., FENG, G. S. and HAMAGUCHI, M. (2003). SH2 domain containing protein tyrosine phosphatase 2 regulates concanavalin $A$-dependent secretion and activation of matrix metalloproteinase 2 via the extracellular signal-regulated kinase and p38 pathways. Cancer Res. 63: 6334-9.
SANCEAU, J., TRUCHET, S. and BAUVOIS, B. (2003). Matrix metalloproteinase9 silencing by RNA interference triggers the migratory-adhesive switch in Ewing's sarcoma cells. J. Biol. Chem. 278: 36537-46.

SATO, H., TAKINO, T., OKADA, Y., CAO, J., SHINAGAWA, A., YAMAMOTO, E. and SEIKI, M. (1994). A matrix metalloproteinase expressed on the surface of invasive tumour cells. Nature. 370: 61-5.

SATO, T., KOIKE, L., MIYATA, Y., HIRATA, M., MIMAKI, Y., SASHIDA, Y., YANO, M. and ITO, A. (2002). Inhibition of activator protein-1 binding activity and phosphatidylinositol 3-kinase pathway by nobiletin, a polymethoxy flavonoid, results in augmentation of tissue inhibitor of metalloproteinases- 1 production and suppression of production of matrix metalloproteinases- 1 and -9 in human fibrosarcoma HT-1080 cells. Cancer Res. 62: 1025-9.

SCHNEIDER, R. M., MEDVEDOVSKA, Y., HARTL, I., VOELKER, B., CHADWICK, M. P., RUSSELL, S. J., CICHUTEK, K. and BUCHHOLZ, C. J. (2003). Directed evolution of retroviruses activatable by tumour-associated matrix metalloproteases. Gene Ther. 10: 1370-80.

SEIKI, M. (2003). Membrane-type 1 matrix metalloproteinase: a key enzyme for tumor invasion. Cancer Lett. 194: 1-11.

SEO, D. W., LI, H., GUEDEZ, L., WINGFIELD, P. T., DIAZ, T., SALLOUM, R., WEI, B. Y. and STETLER-STEVENSON, W. G. (2003). TIMP-2 mediated inhibition of angiogenesis: an MMP-independent mechanism. Cell. 114: 171-80.

SGADARI, C., BARILLARI, G., TOSCHI, E., CARLEI, D., BACIGALUPO, I., BACCARINI, S., PALLADINO, C., LEONE, P., BUGARINI, R., MALAVASI, L., CAFARO, A., FALCHI, M., VALDEMBRI, D., REZZA, G., BUSSOLINO, F., MONINI, P. and ENSOLI, B. (2002). HIV protease inhibitors are potent antiangiogenic molecules and promote regression of Kaposi sarcoma. Nat. Med. 8: 225-32.

SHEU, B. C., HSU, S. M., HO, H. N., LIEN, H. C., HUANG, S. C. and LIN, R. H. (2001). A novel role of metalloproteinase in cancer-mediated immunosuppression. Cancer Res. 61: 237-42.

SHISHODIA, S., MAJUMDAR, S., BANERJEE, S. and AGGARWAL, B. B. (2003). Ursolic acid inhibits nuclear factor-kappaB activation induced by carcinogenic agents through suppression of IkappaBalpha kinase and p65 phosphorylation: correlation with down-regulation of cyclooxygenase 2 , matrix metalloproteinase 9, and cyclin D1. Cancer Res. 63: 4375-83.

SIMON, C., GOEPFERT, H. and BOYD, D. (1998). Inhibition of the p38 mitogenactivated protein kinase by SB 203580 blocks PMA-induced Mr 92,000 type IV collagenase secretion and in vitro invasion. Cancer Res. 58: 1135-9.

SLATON, J. W., KARASHIMA, T., PERROTTE, P., INOUE, K., KIM, S. J., IZAWA, J., KEDAR, D., MCCONKEY, D. J., MILLIKAN, R., SWEENEY, P., YOSHIKAWA, C., SHUIN, T. and DINNEY, C. P. (2001). Treatment with low-dose interferonalpha restores the balance between matrix metalloproteinase- 9 and $E$-cadherin expression in human transitional cell carcinoma of the bladder. Clin. Cancer Res. 7: 2840-53.

SOLBERG, H., RINKENBERGER, J., DANO, K., WERB, Z. and LUND, L. R. (2003). A functional overlap of plasminogen and MMPs regulates vascularization during placental development. Development. 130: 4439-50.

SOUNNI, N. E., DEVY, L., HAJITOU, A., FRANKENNE, F., MUNAUT, C., GILLES, C., DEROANNE, C., THOMPSON, E. W., FOIDART, J. M. and NOEL, A. (2002). MT1-MMP expression promotes tumor growth and angiogenesis through an upregulation of vascular endothelial growth factor expression. FASEB J. 16: 55564.

SOUNNI, N. E., JANSSEN, M., FOIDART, J. M. and NOEL, A. (2003). Membrane type-1 matrix metalloproteinase and TIMP-2 in tumor angiogenesis. Matrix Biol. 22: $55-61$.

STRONGIN, A. Y., COLLIER, I., BANNIKOV, G., MARMER, B. L., GRANT, G. A. and GOLDBERG, G. I. (1995). Mechanism of cell surface activation of 72-kDa type IV collagenase. Isolation of the activated form of the membrane metalloprotease. J. Biol. Chem. 270: 5331-8.

SUN, Y., CHEUNG, J. M., MARTEL-PELLETIER, J., PELLETIER, J. P., WENGER, L., ALTMAN, R. D., HOWELL, D. S. and CHEUNG, H. S. (2000). Wild type and mutant $\mathrm{p} 53$ differentially regulate the gene expression of human collagenase3 (hMMP-13). J. Biol. Chem. 275: 11327-32.

TAKADA, Y. and AGGARWAL, B. B. (2003). Betulinic acid suppresses carcinogeninduced NF-kappa B activation through inhibition of I kappa B alpha kinase and p65 phosphorylation: abrogation of cyclooxygenase-2 and matrix metalloprotease9. J. Immunol. 171: 3278-86. 
TAM, E. M., WU, Y. I., BUTLER, G. S., STACK, M. S. and OVERALL, C. M. (2002). Collagen binding properties of the membrane type-1 matrix metalloproteinase (MT1-MMP) hemopexin C domain. The ectodomain of the 44-kDa autocatalytic product of MT1-MMP inhibits cell invasion by disrupting native type I collagen cleavage. J. Biol. Chem. 277: 39005-14.

TANIMURA, S., ASATO, K., FUJISHIRO, S. H. and KOHNO, M. (2003). Specific blockade of the ERK pathway inhibits the invasiveness of tumor cells: downregulation of matrix metalloproteinase-3/-9/-14 and CD44. Biochem. Biophys. Res. Commun. 304: 801-6.

THOMAS, G. (2002). Furin at the cutting edge: from protein traffic to embryogenesis and disease. Nat. Rev. Mol. Cell Biol. 3: 753-66.

TOWER, G. B., COON, C. I., BELGUISE, K., CHALBOS, D. and BRINCKERHOFF, C. E. (2003). Fra-1 targets the AP-1 site/2G single nucleotide polymorphism (ETS site) in the MMP-1 promoter. Eur. J. Biochem. 270: 4216-25.

UEDA, J., KAJITA, M., SUENAGA, N., FUJII, K. and SEIKI, M. (2003). Sequencespecific silencing of MT1-MMP expression suppresses tumor cell migration and invasion: importance of MT1-MMP as a therapeutic target for invasive tumors. Oncogene. 22: 8716-22.

URIA, J. A., JIMENEZ, M. G., BALBIN, M., FREIJE, J. M. and LOPEZ-OTIN, C. (1998). Differential effects of transforming growth factor-beta on the expression of collagenase-1 and collagenase-3 in human fibroblasts. J. Biol. Chem. 273: 9769-77.

URIA, J. A. and LOPEZ-OTIN, C. (2000). Matrilysin-2, a new matrix metalloproteinase expressed in human tumors and showing the minimal domain organization required for secretion, latency, and activity. Cancer Res. 60: 4745-51.

VAN DEN STEEN, P. E., DUBOIS, B., NELISSEN, I., RUDD, P. M., DWEK, R. A. and OPDENAKKER, G. (2002). Biochemistry and molecular biology of gelatinase B or matrix metalloproteinase-9 (MMP-9). Crit. Rev. Biochem. Mol. Biol. 37: 375-536.

VAN WART, H. E. and BIRKEDAL-HANSEN, H. (1990). The cysteine switch: a principle of regulation of metalloproteinase activity with potential applicability to the entire matrix metalloproteinase gene family. Proc. Natl. Acad. Sci. USA87: 5578-82.

VAZQUEZ, F., HASTINGS, G., ORTEGA, M. A., LANE, T. F., OIKEMUS, S., LOMBARDO, M. and IRUELA-ARISPE, M. L. (1999). METH-1, a human ortholog of ADAMTS-1, and METH-2 are members of a new family of proteins with angio-inhibitory activity. J. Biol. Chem. 274: 23349-57.

VELASCO, G., PENDAS, A. M., FUEYO, A., KNAUPER, V., MURPHY, G. and LOPEZ-OTIN, C. (1999). Cloning and characterization of human MMP-23, a new matrix metalloproteinase predominantly expressed in reproductive tissues and lacking conserved domains in other family members. J. Biol. Chem. 274: 4570-6.

VISSE, R. and NAGASE, H. (2003). Matrix metalloproteinases and tissue inhibitors of metalloproteinases: structure, function, and biochemistry. Circ. Res. 92: 82739.

VU, T. H., SHIPLEY, J. M., BERGERS, G., BERGER, J. E., HELMS, J. A., HANAHAN, D., SHAPIRO, S. D., SENIOR, R. M. and WERB, Z. (1998). MMP$9 /$ gelatinase $B$ is a key regulator of growth plate angiogenesis and apoptosis of hypertrophic chondrocytes. Cell. 93: 411-22.

VU, T. H. and WERB, Z. (2000). Matrix metalloproteinases: effectors of development and normal physiology. Genes Dev. 14: 2123-33.

WESTERMARCK, J. and KAHARI, V. M. (1999). Regulation of matrix metalloproteinase expression in tumor invasion. FASEB J. 13: 781-92.

WIELOCKX, B., LANNOY, K., SHAPIRO, S. D., ITOH, T., ITOHARA, S., VANDEKERCKHOVE, J. and LIBERT, C. (2001). Inhibition of matrix metalloproteinases blocks lethal hepatitis and apoptosis induced by tumor necrosis factor and allows safe antitumor therapy. Nat. Med. 7: 1202-8.

WILLIAMSON, R. A., MARSTON, F. A., ANGAL, S., KOKLITIS, P., PANICO, M., MORRIS, H. R., CARNE, A. F., SMITH, B. J., HARRIS, T. J. and FREEDMAN, R. B. (1990). Disulphide bond assignment in human tissue inhibitor of metalloproteinases (TIMP). Biochem. J. 268: 267-74.
WISEMAN, B. S., STERNLICHT, M. D., LUND, L. R., ALEXANDER, C. M., MOTT, J. BISSELL, M. J., SOLOWAY, P., ITOHARA, S. and WERB, Z. (2003). Site-specific inductive and inhibitory activities of MMP-2 and MMP-3 orchestrate mammary gland branching morphogenesis. J. Cell Biol. 162: 1123-33.

WITTY, J. P., LEMPKA, T., COFFEY, R. J., JR. and MATRISIAN, L. M. (1995) Decreased tumor formation in 7,12-dimethylbenzanthracene-treated stromelysin1 transgenic mice is associated with alterations in mammary epithelial cell apoptosis. Cancer Res. 55: 1401-6.

WOJTOWICZ-PRAGA, S., LOW, J., MARSHALL, J., NESS, E., DICKSON, R., BARTER, J., SALE, M., MCCANN, P., MOORE, J., COLE, A. and HAWKINS, M. J. (1996). Phase I trial of a novel matrix metalloproteinase inhibitor batimastat (BB94) in patients with advanced cancer. Invest. New Drugs. 14: 193-202

WOLF, K., MAZO, I., LEUNG, H., ENGELKE, K., VON ANDRIAN, U. H., DERYUGINA, E. I., STRONGIN, A. Y., BROCKER, E. B. and FRIEDL, P. (2003). Compensation mechanism in tumor cell migration: mesenchymal-amoeboid transition after blocking of pericellular proteolysis. J. Cell Biol. 160: 267-77.

WOO, J. H., LIM, J. H., KIM, Y. H., SUH, S. I., MIN, D. S., CHANG, J. S., LEE, Y. H., PARK, J. W. and KWON, T. K. (2003a). Resveratrol inhibits phorbol myristate acetate-induced matrix metalloproteinase- 9 expression by inhibiting JNK and PKC delta signal transduction. Oncogene. doi:10.1038/sj.onc.1207307.

WOO, J. H., PARK, J. W., LEE, S. H., KIM, Y. H., LEE, I. K., GABRIELSON, E., LEE, H. J., KHO, Y. H. and KWON, T. K. (2003b). Dykellic acid inhibits phorbol myristate acetate-induced matrix metalloproteinase- 9 expression by inhibiting nuclear factor kappa B transcriptional activity. Cancer Res. 63: 3430-4

WYATT, C. A., COON, C. I., GIBSON, J. J. and BRINCKERHOFF, C. E. (2002). Potential for the $2 \mathrm{G}$ single nucleotide polymorphism in the promoter of matrix metalloproteinase to enhance gene expression in normal stromal cells. Cancer Res. 62: 7200-2.

YANA, I. and WEISS, S. J. (2000). Regulation of membrane type-1 matrix metalloproteinase activation by proprotein convertases. Mol. Biol. Cell. 11: 2387 401.

YANG, J., FIZAZI, K., PELEG, S., SIKES, C. R., RAYMOND, A. K., JAMAL, N., HU, M., OLIVE, M., MARTINEZ, L. A., WOOD, C. G., LOGOTHETIS, C. J., KARSENTY, G and NAVONE, N. M. (2001a). Prostate cancer cells induce osteoblast differentiation through a Cbfa1-dependent pathway. Cancer Res. 61: 5652-9.

YANG, Z., STRICKLAND, D. K. and BORNSTEIN, P. (2001b). Extracellular matrix metalloproteinase 2 levels are regulated by the low density lipoprotein-related scavenger receptor and thrombospondin 2. J. Biol. Chem. 276: 8403-8.

YU, C., PAN, K., XING, D., LIANG, G., TAN, W., ZHANG, L. and LIN, D. (2002). Correlation between a single nucleotide polymorphism in the matrix metalloproteinase-2 promoter and risk of lung cancer. Cancer Res. 62: 6430-3.

YU, Q. and STAMENKOVIC, I. (2000). Cell surface-localized matrix metalloproteinase9 proteolytically activates TGF-beta and promotes tumor invasion and angiogenesis. Genes Dev. 14: 163-76.

ZACCHIGNA, S., ZENTILIN, L., MORINI, M., DELL'EVA, R., NOONAN, D. M., ALBINI, A. and GIACCA, M. (2004). AAV-mediated gene transfer of tissue inhibitor of metalloproteinases-1 inhibits vascular tumor growth and angiogenesis in vivo. Cancer Gene Ther. 11: 73-80.

ZHANG, Y., THANT, A. A., MACHIDA, K., ICHIGOTANI, Y., NAITO, Y., HIRAIWA, Y., SENGA, T., SOHARA, Y., MATSUDA, S. and HAMAGUCHI, M. (2002). HyaluronanCD44s signaling regulates matrix metalloproteinase-2 secretion in a human lung carcinoma cell line QG90. Cancer Res. 62: 3962-5.

ZHOU, Z., APTE, S. S., SOININEN, R., CAO, R., BAAKLINI, G. Y., RAUSER, R. W., WANG, J., CAO, Y. and TRYGGVASON, K. (2000). Impaired endochondral ossification and angiogenesis in mice deficient in membrane-type matrix metalloproteinase I. Proc. Natl. Acad. Sci. USA. 97: 4052-7.

ZHU, Y., SPITZ, M. R., LEI, L., MILLS, G. B. and WU, X. (2001). A single nucleotide polymorphism in the matrix metalloproteinase-1 promoter enhances lung cancer susceptibility. Cancer Res. 61: 7825-9.

ZUCKER, S., PEI, D., CAO, J. and LOPEZ-OTIN, C. (2003). Membrane type-matrix metalloproteinases (MT-MMP). Curr. Top Dev. Biol. 54: 1-74 